\title{
Barite encrustation of benthic sulfur-oxidizing bacteria at a marine cold seep
}

E. W. N. Stevens ${ }^{1}$, J. V. Bailey ${ }^{1}$, , B. E. Flood ${ }^{1}$, D. S. Jones ${ }^{1}$, W. P. Gilhooly III ${ }^{2}$, S. B. Joye ${ }^{3}$, A. Teske $^{4}$ and O. U. Mason ${ }^{5}$

1. Department of Earth Sciences, University of Minnesota-Twin Cities, Minneapolis, MN, USA

2. Department of Earth Sciences, Indiana University-Purdue University Indianapolis, Indianapolis, IN, USA

3. Department of Marine Sciences, University of Georgia, Athens, GA, USA

4. Department of Marine Sciences, University of North Carolina at Chapel Hill, Chapel Hill, NC, USA

5. Earth, Ocean, and Atmospheric Science, Florida State University, Tallahassee, FL, USA

*Corresponding author: J. V. Bailey. Tel.: 612624 1603; fax: 612625 3819; e-mail:

baileyj@umn.edu

This is the author's manuscript of the article published in final edited form as:

Stevens, E. W. N., Bailey, J. V., Flood, B. E., Jones, D. S., Gilhooly, W. P., Joye, S. B., ... Mason, O. U. (2015). Barite encrustation of benthic sulfur-oxidizing bacteria at a marine cold seep. Geobiology, 13(6), 588-603. http://doi.org/10.1111/gbi.12154 


\section{Barite encrustation of benthic sulfur-oxidizing 2 bacteria at a marine cold seep}

3

4

5

6 Crusts and chimneys composed of authigenic barite are found at methane seeps and

7 hydrothermal vents that expel fluids rich in barium. Microbial processes have not

8 previously been associated with barite precipitation in marine cold seep settings. Here we

9 report on the precipitation of barite on filaments of sulfide-oxidizing bacteria at a brine

10 seep in the Gulf of Mexico. Barite-mineralized bacterial filaments in the interiors of

11 authigenic barite crusts resemble filamentous sulfide-oxidizing bacteria of the genus

12 Beggiatoa. Clone library and iTag amplicon sequencing of the 16S rRNA gene show that

13 the barite crusts that host these filaments also preserve DNA of Candidatus

14 Maribeggiatoa, as well as sulfate-reducing bacteria. Isotopic analyses show that the sulfur

15 and oxygen isotope compositions of barite have lower $\delta{ }^{34} \mathrm{~S}$ and $\delta{ }^{18} \mathrm{O}$ values than many

16 other marine barite crusts, which is consistent with barite precipitation in an environment

17 in which sulfide oxidation was occurring. Laboratory experiments employing isolates of

18 sulfide-oxidizing bacteria from Gulf of Mexico seep sediments showed that under low

19 sulfate conditions, such as those encountered in brine fluids, sulfate generated by sulfide-

20 oxidizing bacteria fosters rapid barite precipitation localized on cell biomass, leading to

21 the encrustation of bacteria in a manner reminiscent of our observations of barite-

22 mineralized Beggiatoa in the Gulf of Mexico. The precipitation of barite directly on

23 filaments of sulfide-oxidizing bacteria, and not on other benthic substrates, suggests that

24 sulfide oxidation plays a role in barite formation at certain marine brine seeps where

25 sulfide is oxidized to sulfate in contact with barium-rich fluids, either prior to, or during, 
26 the mixing of those fluids with sulfate-containing seawater in the vicinity of the

27 sediment/water interface. As with many other geochemical interfaces that foster mineral

28 precipitation, both biological and abiological processes likely contribute to the

29 precipitation of barite at marine brine seeps such as the one studied here.

\section{INTRODUCTION}

32 The mineral barite $\left(\mathrm{BaSO}_{4}\right)$ is found in diverse depositional environments and is

33 associated with a variety of different geologic processes and pressure-temperature

34 conditions (e.g., Goldberg et al., 1969; Griffith \& Paytan, 2012; Eickmann et al., 2014).

35 Natural waters are typically undersaturated with respect to barite (Chow \& Goldberg,

36 1960; Church \& Wolgemuth, 1972; Monnin et al., 1999; Griffith \& Rushdi et al., 2000;

37 Paytan, 2012), and authigenic barite precipitation occurs when fluids enriched in barium

$38\left(\mathrm{Ba}^{2+}\right)$ encounter those containing sulfate $\left(\mathrm{SO}_{4}^{-2}\right)$ (Ritger et al., 1987; Torres et al., 1996;

39 Greinert et al., 2002; Aloisi et al., 2004), according to Equation 1.

$41 \mathrm{Ba}^{2+}+\mathrm{SO}_{4}{ }^{2-}<=>\mathrm{BaSO}_{4}$

Equation (1)

42 The precipitation of authigenic barite occurs in a variety of depositional settings,

43 including springs, hydrothermal vents and cold seeps (Aquilina et al., 1997; Arenas et

44 al., 2000; Greinert et al., 2002; Torres et al., 2003; Eickmann et al., 2014). In marine

45 systems, precipitation occurs at the seafloor and within the sediment column (Torres et

46 al., 1996; Aquilina et al., 1997; Hanor, 2000; Greinert et al., 2002; Aloisi et al., 2004;

47 Riedinger et al., 2006; Feng \& Roberts, 2011; Griffith \& Paytan, 2012). Diffuse

48 precipitates also form in the water column in association with decaying organic matter 
49 (Bertram \& James, 1997; Stroobants et al., 1991; Dymond et al., 1992; Dehairs et al.,

50 1991; Dehairs et al., 1980; Gonzalez-Muñoz et al., 2012; Goldberg \& Arrhenius, 1958;

51 Bishop, 1988). As an authigenic mineral that reflects the environment of precipitation,

52 barite from diverse depositional environments provides robust paleoenvironmental

53 indicators. For example, geochemical analysis of sedimentary barite offers insight

54 regarding past patterns of marine primary productivity (e.g., Bishop, 1988; Dehairs et al.,

55 1991; Dymond et al., 1992; Gingele \& Dahmke, 1994; Paytan et al., 1996); seawater

56 strontium (e.g., Paytan et al., 1993); redox zone migration (Contreras et al., 2013); and

57 the sulfur isotope composition of marine sulfate from the Cenozoic (e.g., Paytan et al., 58 1998) to the Archean (e.g., Shen et al., 2001).

59 Although barite is thought to form primarily through the abiotic mixing of barium and 60 sulfate-enriched fluids (Hanor, 2000), a number of studies suggest that, under certain 61 conditions, microbial processes play a role in the precipitation of barite (e.g., Bertram \& 62 James, 1997; Rasmussen, 2000; Gonzalez-Munoz, 2003; Senko et al., 2004; Bonny \& 63 Jones, 2007a; Bonny \& Jones, 2007b; Bonny \& Jones, 2008b; Sanz-Montero et al., 2009;

64 Gonzalez-Muñoz et al., 2012; Griffith \& Paytan, 2012). Specific mechanism(s) by which

65 microorganisms mediate barite precipitation vary and are incompletely understood.

66 Potential mechanisms include passive or active biological enrichment of barium (e.g.,

67 Goldberg \& Arrhenius, 1958; Bishop, 1988b; Ganeshram et al., 2003; Bonny \& Jones,

68 2008b), the generation of sulfate via sulfide-oxidation (Spirakis, 1991; Senko et al., 2004;

69 Bonny \& Jones, 2008a), and cellular surfaces acting as nucleation sites for crystal 70 precipitation (e.g., Gonzalez-Munoz, 2003; Gonzalez-Muñoz et al., 2012). 
71 Sulfate produced during lithotrophic sulfide oxidation is generally only thought to

72 contribute to barite precipitation in sulfate-depleted settings such as terrestrial springs

73 (Bonny \& Jones, 2008a). Sulfide oxidation in the marine environment has not previously

74 been associated with barite precipitation because of the ubiquity of dissolved sulfate (28

$75 \mathrm{mM}$ ) in seawater. In contrast to those of terrestrial springs, marine authigenic barites

76 have, in fact, been noted for their paucity of "biological textures" (Bonny \& Jones,

77 2008b). The canonical view is that barite precipitating at marine cold seeps is driven

78 exclusively by the abiotic mixing of barium-rich, sulfate-free fluids with seawater rich in

79 sulfate (Fu et al., 1994; Torres et. al. 1996; Aquilina et al., 1997; Castellini et al., 2006;

80 Roberts et al., 2010). However, the relative contribution of sulfate produced during

81 sulfide oxidation may become significant in certain marine pore waters where microbial

82 sulfate reduction consumes dissolved sulfate and barite is remobilized by reductive

83 dissolution (Fritz et al., 1989; Greinert et al., 2002; Torres et al., 2003), or where the

84 active precipitation of authigenic barite can temporarily deplete local sulfate supply

85 (Feng \& Roberts, 2011). Additionally, some subsurface fluids, including those that are

86 enriched in barium, lack sulfate (Joye et al., 2009). In sulfate-free marine settings such as

87 these, lithotrophic sulfide oxidation could drive precipitation of authigenic barite, though

88 specific evidence for this process has not, to our knowledge, been presented.

89 The seepage of hypersaline fluids from subsurface reservoirs can lead to the formation

90 of pools containing high-density fluids on the seafloor. Brine pools are known from the

91 Red Sea, the Black Sea, the Mediterranean and the Gulf of Mexico (Addy \& Behrens,

92 1980; Eder et al., 1999; van der Wielen et al., 2005; Daffonchio et al., 2006). Brine

93 fluids are rich in dissolved organic carbon that may stimulate dissimilatory sulfate 
94 reduction, generating sulfide that supports the growth of sulfide-oxidizing bacteria and

95 sustains the establishment of animal communities that depend on chemoautotrophic

96 microbial symbionts (MacDonald et al., 1990; Greinert et al., 2002; Orcutt et al., 2005).

97 Certain brine seepage and mud volcano sites in the Gulf of Mexico also hosts extensive

98 authigenic barite deposits that occur where barium-rich, sulfate-free brine fluids

99 encounter seawater sulfate (Fu et al., 1994; Castellini et al., 2006; Roberts et al., 2010).

100 During exploration of one of these brine pools in the Gulf of Mexico, we discovered

101 barite crusts that contain dense networks of barite-mineralized filaments internally. The

102 mineral filaments resemble Beggiotoa, a filamentous sulfide-oxidizing bacterium that is

103 extremely abundant in the microbial mats at this site. Putative Beggiatoa-like

104 microorganisms have been shown previously to be preserved as fossils in ancient 105 phosphorites and methane seep carbonates (Cavagna et al., 1999; Peckmann et al., 2004;

106 Barbieri \& Cavalazzi, 2005; Bojanowski, 2007; Bailey et al., 2013), but have not been

107 identified previously in barite. Here we report on the results of imaging, mineralogical

108 characterization, and sequencing of relict DNA recovered from within the barite-

109 mineralized filaments. We complemented these analyses with laboratory experiments and

110 isotopic analyses to further resolve the role of bacterial sulfide oxidation in the

111 precipitation of the filament-hosting barite mineral crusts.

112

\section{MATERIALS AND METHODS}

\section{Sample Localities}

115 Green Canyon Block 246 (GC246) is located on the upper mid-continental slope of the 116 Gulf of Mexico, approximately 200 km southwest of the Mississippi River Delta. This 
117 region has a complex geology influenced by extensive sedimentation, sea-level changes

118 and salt tectonics that create geochemical conditions, conduits, and topography that allow

119 for the formation of mud volcanoes and brine seepage features (Joye, 2005; Roberts et

120 al., 2010). Dead Crab Lake is a shallow brine pool approximately $15 \mathrm{~m}$ wide and 15-20

121 cm deep, located at a water depth of $867 \mathrm{~m}\left(27^{\circ} 42.1985^{\prime} \mathrm{N}, 90^{\circ} 39.0112^{\prime} \mathrm{W}\right)$. Barite crusts

122 and chimneys, as well as extensive orange and white-colored microbial mats that were

123 visually dominated by dense Beggiatoa filaments, were encountered along the shoreline

124 of Dead Crab Lake (Fig. 1A). Samples of the mineral crust and chimney structures were

125 collected using the DSV Alvin during dives 4651, 4652 \& 4656 (November, 2010) on a

126 research cruise on the R/V Atlantis (Cruise AT 18-02).

\section{Observations and Sample Characterization}

129 Initial observations and images of the barite mineral crusts and chimney samples were

130 made using an Olympus SZX16 stereomicroscope on board the R/V Atlantis immediately

131 after sample collection. Samples were split for microscopy and molecular biology using

132 sterilized tools, with the latter sample splits being frozen immediately at $-80^{\circ} \mathrm{C}$. Mineral

133 crust samples were later imaged using a Hitachi T-1000 SEM scanning electron

134 microscope operating at an acceleration voltage of $15 \mathrm{kV}$. Semi-quantitative element

135 abundances were measured using energy-dispersive $\mathrm{x}$-ray spectroscopy (EDS) running

136 Bruker's Quantax 50 software, with acquisition times of 90 seconds for EDS spectra.

137 Bulk mineralogical analysis of the dried mineral crust was performed using a Rigaku

138 Miniflex powder X-ray diffraction (XRD). The x-ray source was a $\mathrm{Cu}$ anode operated at

$13930 \mathrm{kV}$ and $15 \mathrm{~mA}$ using $\mathrm{CuK} \alpha$ radiation. Scans were taken at $2^{\circ}$ per minute and covered 
140 an angular region of $15^{\circ} \leq 2 \theta \leq 65^{\circ}$. Mineral spectra were identified using the XRD

141 analysis software JADE (Materials Data Incorporated, USA).

142

143 DNA Recovery from Barite Filaments and 16S rRNA Gene Analysis

144 Sample preparation and DNA extraction

145 In order to obtain mineral-hosted DNA that was free of contamination on external 146 surfaces, barite crust samples containing mineralized filaments were washed prior to 147 sample homogenization and DNA extraction. Washing followed a procedure similar to 148 that used by Mason et al. (2015). For each wash step, samples were rinsed in syringe-

149 filtered 1x phosphate buffered saline (PBS), followed by sonication at 160 watts for 15

150 seconds. Samples were then centrifuged for 5 minutes at $4000 \times$ g. Supernatant was

151 removed and fresh PBS added for a total of nine rinses. The third, sixth and ninth rinsate

152 was collected and tested for the presence of amplifiable DNA via PCR using bacterial-

153 specific primers $27 \mathrm{~F}$ and $1492 \mathrm{R}$ and the Beggiatoa-specific primer pair $341 \mathrm{~F}$ and

154 VSOXBr (See primer details in Table S2).

155 After 9 wash steps, no amplifiable DNA was detected in the rinsate. Following 156 homogenization, DNA was then extracted from the barite crust (one $0.6 \mathrm{~g}$ sample) using 157 the Powersoil DNA Isolation Kit (Mo Bio Laboratories, USA) following the 158 manufacturer's protocol, with two modifications. First, prior to bead beating, samples

159 were incubated at $65^{\circ} \mathrm{C}$ for 5 minutes, vortexed briefly, and returned to $65^{\circ} \mathrm{C}$ for 5 160 minutes. Second, bead beating was performed for 5, 8 and 10 minutes, followed by the 161 pooling of supernatants, in order to reduce extraction biases based on cell type. 
164 An Illumina tag (iTag) amplicon library of the V3 hypervariable region of the 16S

165 rRNA gene was generated using an approach similar to that of Bartram et al. (2011). The

166 V3 region was amplified via polymerase chain reaction (PCR) using the Illumina-specific

167 adaptor-primers of Bartram et al. (2011) modified to include a degenerate sequence of 4-

1687 nucleotides (e.g., NNNN) between the adapter sequences and the primers to improve

169 cluster identification during Illumina sequencing. PCR reactions were performed using

170 the HotStarTaq Plus enzyme (Qiagen, USA), with 5 minute initial denaturation at $95{ }^{\circ} \mathrm{C}$,

17125 cycles of denaturation ( $95^{\circ} \mathrm{C}, 1$ minute), annealing (50 ${ }^{\circ} \mathrm{C}, 1$ minute), and elongation

172 (72 ${ }^{\circ} \mathrm{C}, 1$ minute), and 7 minute final elongation $\left(72^{\circ} \mathrm{C}\right)$. Gel electrophoresis was used to

173 separate DNA products from primers and primer dimers using a $2 \%$ agarose gel. Bands

174 were cut out and purified using the Zymoclean Gel DNA Recovery Kit (Zymo Research,

175 Orange, CA). Itag amplicon libraries were sequenced via 150 cycles of paired-end

176 Illumina MiSeq at the University of Minnesota Genomics Center (UMGC).

177 Raw sequences were quality trimmed and filtered using Fastq-MCF (Aronesty, 2011)

178 and reads with adaptor sequences removed using cutadapt (Martin, 2011). Forward and

179 reverse sequences were assembled using PAired-eND Assembler (Masella et al., 2012).

180 Chimeras were removed using UCHIME (Edgar et al., 2011). Sequence data was then 181 processed using mothur (Schloss et al., 2009) within the Galaxy platform (Blankenberg et 182 al., 2010; Giardine et al., 2005), which was used to classify sequences according to 183 SILVA taxonomic assignments (Quast et al., 2013). Operational taxonomic units (OTUs) 184 were defined at $97 \%$ similarity using default parameters. Rarefaction analyses of both the 185 general 16S rRNA gene clone library and the 16S rRNA gene Illumina amplicon data sets 
186 were also performed using mothur (Schloss et al., 2009). Amplicon sequences were

187 deposited in the Sequence Read Archive (http://www.ncbi.nlm.nih.gov/sra) under project

188 ID PRJNA267505.

190 Clone libraries

191 Two 16S rRNA gene clone libraries were generated. The first used the general bacterial 192 primers 27F and 1492R (Table S2) to improve phylogenetic resolution of the dominant 193 taxa. A second clone library was generated using the primer pair VSOXBr and 341f 194 (Table S2) in order to target representatives of the Beggiatoaceae that are commonly 195 missed by widely-used general primer sets (Kalanetra et al., 2005). Amplification using $196341 \mathrm{~F}$ and VSOXBr required two consecutive PCRs using the same primer sets, an 197 approach described in Salman et al. (2011). PCR reactions $(25 \mu \mathrm{l})$ were incubated as 198 follows: initial denaturation of 4 minutes at $95{ }^{\circ} \mathrm{C}, 6$ cycles of touchdown PCR consisting 199 of 45 seconds of denaturation at $95^{\circ} \mathrm{C}$, annealing for 45 seconds at temperatures of $59^{\circ} \mathrm{C}$, $20057^{\circ} \mathrm{C}, 55^{\circ} \mathrm{C}$, and elongation for 45 seconds at $72{ }^{\circ} \mathrm{C}$, followed by 24 cycles of PCR at an 201 annealing $53^{\circ} \mathrm{C}$ for 45 seconds, with a final elongation step at $72{ }^{\circ} \mathrm{C}$ for 7 minutes. PCR 202 products were then cloned using the Topo TA cloning kit (Invitrogen, USA). PCR 203 products were cleaned using a DNA Clean and Concentrator -5 kit (Zymo Research, 204 USA. Sanger sequencing was performed at the UMGC with a capillary ABI 3730xl 205 sequencer and ABI BigDye Terminator version 3.1 chemistry (Applied Biosystems, 206 USA). Partial sequences were assembled using Sequencher (Bromberg et al., 1995) with 207 final sequence lengths of $>1300$ bp reads for the general bacterial library and $>500$ bp 
208 reads for the Beggiatoa specific library. Clone library sequences were archived under

209 GenBank accession numbers KM396655-KM396693.

211 Phylogenetic analysis

212 The 16S rRNA gene sequences from the general bacterial and Beggiatoa-specific clone

213 libraries were aligned using the NAST aligner within the Greengenes web application

214 (DeSantis et al., 2006). The sequences were then added to an ARB database of nearly

215 480,000 representative bacterial sequences. Manual refinement was performed in ARB

216 using the ARB_Edit4 sequence editor. Alignments were trimmed so that all sequences

217 were of equal length, and nucleotide positions with less than $50 \%$ base-pair conservation

218 were masked. The final alignment lengths were 1320 and 512 nucleotide positions for the

219 general bacteria library and Beggiatoa specific library respectively. Neighbor joining 220 analyses were performed in PAUP* version $4 \mathrm{~b} 10$ (Swofford, 1999) with Jukes-Cantor

221 (JC) corrected distance matrix and 2000 bootstrap replicates.

222

\section{Precipitation Experiments}

224 To investigate the mechanisms by which sulfide-oxidizing bacteria might induce barite 225 precipitation via the generation of sulfate in barium-rich solutions, experiments were 226 conducted using five pure culture isolates. Two of these isolates, namely Thiomicrospira 227 crunogena strain XCL-2 (Jannasch et al. 1985; Scott 2006) $($ ATCC $=35932 ;$ DSMZ = 228 25203) and Sedimenticola thiotaurini strain SIP-G1 (Flood et al., 2015) (ATCC = BAA-

229 2640; DSMZ = 28581), were selected because they are known to oxidize sulfide and 230 thiosulfate. S. thiotaurini SIP-G1 was isolated from Sippewissett Salt Marsh, MA. T. 
231 crunogena XCL-2 was originally isolated from hydrothermal sulfides of the East Pacific

232 Rise (Jannasch et al., 1985). We isolated three additional strains from sediment collected

233 in the Gulf of Mexico (Site GC233) near the site of barite crust collection. These

234 organisms were isolated on the experimental precipitation medium agar plates described

235 below, with the addition of thiosulfate, but without the addition of barium. These strains

236 were taxonomically characterized by amplification and analysis of 16S rRNA genes as

237 described for the clone libraries. The three strains are herein referred to as Halomonas

238 sp., strain BM23 (KP336666), Maribacter sp. strain LM2 (KP336667) and Roseobacter

239 sp. strain LH4 (KP336667).

241 PCR amplification using soxB specific primers, soxB693F and soxB1446B (Petri et al., 242 2001), was performed on all five isolates in order to assess the presence or absence of a

243 Sox pathway, a pathway that diverse lithotrophs use to oxidize sulfur (Mukhopadhyaya et

244 al., 2000; Kappler \& Dahl, 2001),. PCR analysis showed that Roseobacter sp. LH4, S.

245 thiotaurini, and T. crunogena were positive for soxB. No soxB gene amplification was

246 observed for Maribacter and Halomonas. Halomonas sp. strain BM23 was chosen for

247 inclusion in these experiments because previous work with related bacteria (Teske et al.,

248 2000) suggested that its sulfur metabolism generates tetrathionate (and perhaps sulfate),

249 but at a slower rate than the other sulfur-oxidizing strains selected here. Maribacter sp.

250 strain LM2, a organoheterotroph, was chosen as a control strain because it does not likely

251 have the capability to oxidize thiosulfate, but grows on the same plates as the other

252 bacteria probably via the degradation of trace organics or structural proteins within the 253 agar. 
254 Precipitation experiments and bacterial isolations were conducted using an agar base 255 medium with the following composition: $430 \mathrm{mM} \mathrm{NaCl}, 6.0 \mathrm{mM} \mathrm{MgCl} 26 \mathrm{H}_{2} 0,2.0 \mathrm{mM}$ $256 \mathrm{CaCl}_{2}, 3.3 \mathrm{mM} \mathrm{NH}_{4} \mathrm{Cl}, 3.1 \mathrm{mM} \mathrm{K} \mathrm{HPO}_{4}, 10 \mathrm{mM}$ Tris.Cl buffer, , 0.005\% phenol red 257 (w/v), 1x SL-8 trace metal solution (Biebl and Pfennig, 1978) and 1.5\% technical grade 258 agar (w/v) (BD Difco). Plates used during precipitation experiments consisting of the 259 base media supplemented with $2 \mathrm{mM} \mathrm{BaCl}_{2}$ and $10 \mathrm{mM} \mathrm{Na}_{2} \mathrm{~S}_{2} \mathrm{O}_{3}$. Phenol red was used as $260 \mathrm{a} \mathrm{pH}$ indicator and base media was adjusted to $\mathrm{pH}$ 7.92. These plates were designed to 261 promote thiosulfate oxidation coupled with autotrophic growth whereby $\mathrm{NH}_{4}$ and $\mathrm{PO}_{4}$

262 serve as inorganic sources of $\mathrm{N}$ and $\mathrm{P}$. Although Tris $\mathrm{Cl}$ provides some initial buffering 263 capacity to promote microbial growth, sufficient levels of acid or base production around 264 a microbial colony turns the phenol red yellow for acid production and fushia for base 265 production. Prior to initiation of precipitation experiments, all isolates were cultured in 266 liquid Marine Broth 2216 (BD Difco) except for T. crunogena, which was cultured in 267 liquid TMS media (Jannasch et al., 1985). All cultures were incubated for 72 hours at $25^{\circ}$ $268 \pm 1^{\circ}$ prior to inoculation of the barite precipitation experiments.

269 Aliquots $(20 \mu \mathrm{l})$ of the liquid culture inocula were spread on the experimental plates. 270 Petri dishes were stored benchtop at $25^{\circ} \pm 1^{\circ}$. S. thiotaurini was grown in a Coy hypoxic 271 chamber $\left(5 \% \mathrm{O}_{2}\right)$ due to its sensitivity to oxygen - a characteristic that it shares with 272 some closely related sulfide-oxidizing gammaproteobacteria, including marine Beggiatoa 273 strains. Experiments were monitored daily for cell growth, mineral precipitation, and 274 changes in $\mathrm{pH}$. Plates with $2 \mathrm{mM} \mathrm{BaCl}_{2}$ and $\sim 10 \mathrm{mM} \mathrm{Na}_{2} \mathrm{~S}_{2} \mathrm{O}_{3}$, but without cell inocula, 275 were used as cell-free control experiments. Additional controls were also performed 
276 using cells fixed in a $4 \%$ paraformaldehyde in seawater solution incubated at $4^{\circ} \mathrm{C}$ for 3

277 hours.

278

279 Isotopic Analysis

280 The sulfur $\left(\delta^{34} \mathrm{~S}\right)$ and oxygen $\left(\delta^{18} \mathrm{O}\right)$ isotopic compositions of barite powders drilled

281 from barite crusts, barite-mineralized filaments and barite chimneys, were measured on a

282 stable isotope ratio mass spectrometer (IRMS; Thermo Delta V Plus at IUPUI). Barites

283 were weighed $(0.4 \mathrm{mg})$ into tin capsules and mixed with vanadium pentoxide to promote

284 complete combustion to $\mathrm{SO}_{2}$ in an elemental analyzer (Costech Analytical ECS 4010),

285 which was coupled under continuous flow to the IRMS. A separate barite split (0.15 mg)

286 was weighed into silver capsules and mixed with an equal mass of graphite. Sulfate-

287 oxygen was converted to CO by pyrolysis (Thermo TC/EA) and the sample gas was

288 transferred by helium carrier gas to the IRMS for oxygen isotope analysis. Isotope values

289 were reported in standard delta notation $\left[\delta^{x} E=\left(R_{\text {sample }} / R_{\text {standard }}-1\right)\right.$ x1000] for each

290 isotope $\left({ }^{\mathrm{X}} \mathrm{E}={ }^{34} \mathrm{~S}\right.$ or $\left.{ }^{18} \mathrm{O}\right)$ by normalizing the isotopic ratio $\left(\mathrm{R}={ }^{34} \mathrm{~S} /{ }^{32} \mathrm{~S}\right.$ or $\left.{ }^{18} \mathrm{O} /{ }^{16} \mathrm{O}\right)$ of the

291 sample to the isotopic ratio of the international standard for sulfur, Vienna Canyon

292 Diablo Troilite (VCDT), and Standard Mean Ocean Water (SMOW) for oxygen. Sulfur

293 isotope values were calibrated against international reference materials NBS-127 $\left(\delta^{34} \mathrm{~S}=\right.$

$29421.1 \%$ ), IAEA-SO5 $\left(\delta^{34} \mathrm{~S}=0.49 \%\right)$, and IAEA-SO6 $\left(\delta^{34} \mathrm{~S}=-34.05 \%\right)$. Oxygen isotope

295 values were normalized to reference materials IAEA-SO6 $\left(\delta^{18} \mathrm{O}=-11.0 \%\right)$, NBS-127

$296\left(\delta^{18} \mathrm{O}=8.7 \%\right)$, and IAEA-SO5 $\left(\delta^{18} \mathrm{O}=12.0 \%\right)$. Linear regression was used to correct

297 unknowns to the international reference values and to account for scale compression.

298 Analytical precision for $\delta^{34} S$ and $\delta^{18} \mathrm{O}$ values of reference materials was $\pm 0.2 \%$ o $(1 \sigma)$. 


\section{RESULTS}

\section{Observations and mineralogical characterization of mineral filaments}

302 A complex assemblage of mineral crusts, chimneys, brine flow channels, and microbial 303 mats containing abundant Beggiatoa surround the Dead Crab Lake brine pool (Fig. 1A).

304 Fist-sized samples of mineral crust and small cone-shaped chimney structures were 305 collected using the DSV Alvin (Table S2). As with other barite crusts and chimneys from 306 the Gulf of Mexico, the samples collected were relatively porous and friable.

307 Examination of the freshly collected crust using a dissecting microscope revealed a dense 308 network of mineral filaments in the interiors of several barite crust samples (Fig. 1B).

309 Living unmineralized filamentous sulfur bacteria resembling Beggiatoa were observed on

310 crust exteriors, but in much lower abundance than in the microbial mats from the

311 sediments in the vicinity of the crusts. Examination of the crusts using scanning electron

312 microscopy revealed fully mineralized filaments and some organic bacterial filaments

313 that were partially coated or encrusted by barite (Fig. 1C-D). As these filaments

314 accumulate precipitates, they appear to grow thicker (sometimes substantially thicker

315 than the original cell) and the filamentous morphology grades into an amorphous mineral

316 texture (Fig. 1, Fig. S1). XRD analysis revealed that the mineral crusts and filament-

317 encrusting minerals are composed principally of barite (Fig. S2).

\section{Analysis of mineral-hosted DNA}

320 DNA was extracted from the barite to determine whether the mineralized filaments 321 preserved molecular signatures of Beggiatoa or other sulfide-oxidizing bacteria that may 
322 have influenced barite precipitation. iTag amplicon sequencing of the 16S rRNA gene

323 provided a broad picture of the community DNA preserved within the mineral matrix of

324 the filament-hosting barite crust, while clone libraries were used to obtain greater

325 phylogenetic resolution of certain abundant taxa.

326 The Illumina MiSeq iTag amplicon library produced 102,664 sequences for the single

327 filament-hosting barite crust sample. The most abundant sequences fell within the

328 Proteobacteria, with gammaproteobacterial sequences comprising $37.7 \%$ of the sequences

329 and alphaproteobacterial sequences comprising $16.2 \%$ (Figure 2 ). Of the

330 gammaproteobacterial sequences, $20 \%$ fell within the Thiotrichales ${ }^{1}$, including 38

331 sequences from within the family Beggiatoaceae. Of the alphaproteobacterial sequences,

332 Roseobacter was the most abundant genus, comprising 38\% of the sequences. The most

333 abundant sequences within the Epsilonproteobacteria fell within the genera Sulfurovum,

334 Sulfuricurvum, Sulfurospirillum, and Sulfurimonas comprising 58\%, 18\%, 16\%, and

$3354.6 \%$ of the epsilonproteobacterial sequences respectively. Molecular signatures of

336 sulfate-reducing bacteria were also present within the crust. Of the deltaproteobacterial

337 sequences 32\%, 26\%, and 5\% were of the order Desulfobacterales, Desulfuromonadales,

338 and Desulfovibrionales respectively.

339 Thirty-eight nearly full-length 16S rRNA gene sequences were generated from the

340 bacterial clone library of the same sample used to generate the amplicon library, here

341 using the primer set $27 \mathrm{~F}$ and $1492 \mathrm{R}$ (Table S2). A neighbor-joining tree shows

\footnotetext{
${ }^{1}$ The "Thiotricales" is a polyphyletic assemblage of mutually distinct families including the Beggiatoaceae (Salman et al., 2011). Here we refer to the Thiotricales for the purposes of maintaining consistency with the current Silva taxonomy that is used for phylogenetic assignment of iTag sequences in this report.
} 
342 phylogenetic relationships of the sequences from the general bacterial 16S rRNA gene

343 clone library (Fig. 3). Numerous sequences in the clone library record the presence of

344 sulfide-oxidizing bacteria in the depositional environment from which the barite crusts

345 precipitated (Highlighted in Figure 3). Seven sequences fell within the

346 Alphaproteobacteria and grouped with the family Rhodobacteraceae, which include the

347 known sulfide-oxidizing bacteria genera Roseobacter, Sulfitobacter, and Roseovarius

348 (Buchan et al., 2005). Four sequences fell within the Epsilonproteobacteria, two of which

349 grouped with Sulfurospirillum and two of which grouped with Sulfurovum, both known

350 sulfide-oxidizing bacteria (Campbell et al., 2006). Other phylotypes in the clone library

351 fell within the Bacteroidetes, Firmicutes, and unclassified bacteria. The clade-specific

352 clone library targeting the Beggiatoaceae, again from the same barite sample, used

353 primers 341F and VSOXbR (Salman et al., 2011) (Figure 2), and produced nine

354 sequences, two of which clustered with Candidatus Maribeggiatoa vulgaris (Fig. 3, 355 green-labels).

356 Precipitation Experiments

357 Laboratory cultures of four sulfur-oxidizing bacteria and one organoheterotrophic 358 control organism were incubated on barium-rich media to observe the influence of sulfate 359 generation via sulfur oxidation under barium-rich, sulfate-poor conditions. Such 360 conditions are encountered in brine pool settings like that of Dead Crab Lake where 361 mineralized Beggiatoa filaments were discovered. Beggiatoa spp. were not selected as

362 test strains because a marine Beggiatoa culture was not available and because Beggiatoa 363 enrichments require gradient media and other geochemical conditions that make them 364 impractical for these mineral precipitation experiments. Thiosulfate was used instead of 
365 sulfide because it is easier to manipulate in laboratory experiments. Thiosulfate is readily

366 oxidized by diverse lithotrophs that also oxidize hydrogen sulfide, and its oxidation also

367 yields sulfate and protons, the chemical species thought relevant to barite precipitation:

$368 \quad \mathrm{~S}_{2} \mathrm{O}_{3}{ }^{2-}+\mathrm{H}_{2} \mathrm{O}+2 \mathrm{O}_{2} \rightarrow 2 \mathrm{SO}_{4}{ }^{2-}+2 \mathrm{H}^{+}$

Equation 4

369 Development of observable barite precipitates varied between the five experimental

370 isolates. Barite precipitation was observed in Roseobacter sp. colonies on the third day of

371 the experiment (Figure 1F, Figure S4). Thiomicrospira crunogena showed barite

372 precipitation by the fourth day of the experiment. S. thiotaurini colonies exhibited barite

373 precipitates on the tenth day after inoculation. Halomonas sp. exhibited no barite or other

374 mineral precipitation until 45 days after inoculation. Density, concentration, and location

375 of the precipitates associated with Halomonas sp. were similar to those exhibited by the

376 other sulfur-oxidizing bacteria. Barite precipitates developed by the twelfth day on

377 plates with the heterotrophic control isolate, Maribacter sp.; although unlike with the

378 other isolates where minerals precipitated directly and exclusively on the colony biomass,

379 Maribacter-associated precipitates were always restricted to a circular halo $\sim 5 \mathrm{~mm}$ away

380 from the colony (Figure S4). Barite precipitates were not observed to form on colony

381 biomass with Maribacter, in direct contrast to the sulfide-oxidizing bacterial isolates

382 tested. Mineral precipitates on colonies (or in the region surrounding the colonies in the

383 case of Maribacter sp.) were characterized using an XRD microdiffractometer. XRD

384 analysis of all five bacterial isolates show peaks that closely resemble reference peaks for

385 barite (Fig. S3). Uninoculated control plates showed no mineral-precipitation or XRD

386 signal. PFA-fixed cells were also examined and no mineral precipitation was observed

387 with the PFA-fixed controls. 
389 occurred before mineral precipitation was easily observed by eye on the agar plates. In

390 the case of T. crunogena, Roseobacter sp. and S. thiotaurini the agar around the cell

391 colonies turned yellow from acid production. Initial growth of the halomonad, on the

392 other hand, resulted in a darkening or more fuchsia appearance of the agar plate

393 suggestive of tetrathionate production. But after 45 days the agar plates returned to their

394 original color and barite crystals were observed. Lastly, growth of Maribacter sp. turned

395 the agar plate slightly more yellow but the $\mathrm{pH}$ change occurred more diffusely throughout

396 the agar plate and was not localized around the bacterial colonies.

399 Sulfur and oxygen isotopes of barites

400 Sulfur and oxygen isotopic compositions of barite mineralized filaments, barite crusts, 401 and subsamples of barite chimneys are provided in Table S1 and plotted in Figure 4. The

402 barite samples studied here show little variability between samples, with $\delta^{34} S$ values that 403 ranged from 21.2 to $21.9 \%$, and $\delta^{18} \mathrm{O}$ that ranged from 9.6 to $10.4 \%$. Although slightly 404 enriched in ${ }^{34} \mathrm{~S}$ and ${ }^{18} \mathrm{O}$ relative to Gulf of Mexico bottom water sulfate $\left[\delta^{34} \mathrm{~S}=20.3 \%\right.$, 405 and $\delta^{18} \mathrm{O}=9.7 \%$ (Aharon $\& \mathrm{Fu}, 2000$ )], GC246 barites have lower $\delta^{34} \mathrm{~S}$ and $\delta^{18} \mathrm{O}$ values 406 in comparison to other barite samples from the Gulf of Mexico reported by (Feng \& 407 Roberts, 2011) (Fig. 4).

408

409 DISCUSSION

410 Barite mineral filaments are encrusted Beggiatoa 
411 The sediments on the shoreline of Dead Crab Lake were covered with microbial mats

412 predominated by filamentous sulfide-oxidizing Beggiatoa sp. ${ }^{2}$ (Fig. 1A). The barite-

413 mineralized filaments preserved in crust samples from two sites at GC246 at the margins

414 of these mats are of similar size and morphology to Beggiatoa, and sometimes exhibit

415 apparent septations that resemble the linear arrangement of cells within the trichomes of

416 Beggiatoa, (Fig. 1C). Additionally, the observation of unmineralized and partially

417 mineralized Beggiatoa (Fig. 1D, E), in and on the same samples that contain the barite

418 mineral filaments suggests a continuum in the encrustation of Beggiatoa, from

419 completely mineral-free, to partially mineralized, to fully mineral-encrusted filaments

420 that become a structural component of the barite crust. Our conclusion that the mineral

421 filaments are encrusted Beggiatoa is further supported by the recovery of 16S rRNA

422 genes closely related to Candidatus Maribeggiatoa vulgaris in the clone libraries that

423 were produced from samples that contain mineralized filaments (Fig. 3). While it is

424 possible that living cells were present in void spaces within the crust, the lack of

425 amplifiable DNA in rinsate fluids tested prior to DNA extraction from the crust, as well

426 as the presence of partially mineralized Beggiatoa filaments in portions of the crust,

427 suggest that at least some of the Beggiatoa DNA is coeval with barite precipitation. It is

428 not surprising that Maribeggiatoa 16S rRNA gene sequences represent a relatively minor

429 portion of the libraries here, given that numerous other studies have reported difficulties

430 with amplifying 16S rRNA gene sequences from samples visibly dominated by

\footnotetext{
${ }^{2}$ We use "Beggiatoa" here to refer to the polyphyletic group of non-sheath-forming filamentous sulfide-oxidizing bacteria within the family Beggiatoacaea. Sequence data suggest that at least some of the organisms in the "Beggiatoa" mats are representatives of the candidate genus Ca. Maribeggiatoa (Salman et al., 2011).
} 
431 Beggiatoa and related organisms in the family Beggiatoaceae (e.g., Sekar 2006; Salman 432 et al., 2012; Jones et al., 2015).

433 In the barite crust samples studied here, bacterial filaments are the only identifiable

434 organic surfaces covered with barite crystals and void space was observed between some 435 neighboring filaments (Fig. 1B). Regions containing dense accumulations of obvious 436 mineral filaments are commonly surrounded by massive barite crusts that gradationally 437 exhibit less filamentous textures (Fig. S1). Dense networks of mineral filaments can take 438 on a clotted appearance similar to the more massive barite crystal aggregates that make 439 up the bulk of the crust exterior (Fig. S1). These microfacies relationships suggest that, at 440 least in the samples we examined, precipitation was initiated on the filaments and these 441 initial precipitates served as a foundation for the precipitation of a more massive 442 authigenic crust. Fig. 1C-D shows barite crystallites precipitating preferentially on

443 Beggiatoa filaments. Whether mineralized filaments are foundational to the extensive 444 authigenic barite crusts present at this site, or other brine seeps, remains an open 445 question. However, samples containing mineralized filaments were collected on two 446 separate submersible dives in three different samples collected at GC246, so they are 447 clearly common at this site. Other benthic substrates such as rocks, sediment grains, and 448 mussel shells, were not encrusted by barite at this site.

449 In addition to hosting the molecular remains of Candidatus Maribeggiatoa, the filament450 hosting crusts from the Gulf of Mexico also contain genetic material from other bacteria, 451 including other known sulfide-oxidizing bacteria (Figs. 2-3). Broad phylogenetic trends 452 observed in the 16S rRNA gene iTag amplicon library of mineral-hosted DNA were very 453 similar to those obtained in the bacterial clone library (Fig. 2). Both the clone library and 
454 the iTag amplicon dataset showed that diverse sulfide-oxidizing bacteria were present in

455 the microenvironment from which the barite precipitated. The recovery of sequences

456 representing taxa within the orders Desulfobacterales, Desulfuromonadales, and

457 Desulfovibrionales (Figure 2) further suggest that sulfate reduction may have been

458 occurring in close spatial proximity to sulfide oxidation, and that a community actively

459 involved in sulfur cycling was entombed by barite precipitation.

460

461 Is barite encrustation of cells induced by sulfide-oxidation?

462 The generation of sulfate by sulfide-oxidizing bacteria is thought to promote barite 463 precipitation in certain modern non-marine settings where sulfate is absent or found only 464 in low concentrations (Senko et al., 2004; Bonny \& Jones, 2008a). Bacterial sulfide465 oxidation has also been invoked to explain the patchy occurrence of authigenic barite in 466 Miocene lake deposits (Sanz-Montero et al., 2009). In the marine environment where 467 sulfate is abundant, bacterial sulfide oxidation is not considered relevant to barite 468 precipitation. However, certain brine fluids, such as those at Dead Crab Lake, are 469 enriched in barium and free of measurable sulfate, raising the possibility that sulfate 470 production via lithotrophic sulfide oxidation leads to barite precipitation.

471 We exposed laboratory cultures of sulfide-oxidizing bacteria and organoheterotrophic 472 control organisms to barium-rich culture conditions to determine whether sulfide473 oxidation would promote rapid cell barite encrustation of cell material, reminiscent of 474 what is observed in the barite-encrusted Beggiatoa from the Gulf of Mexico. Barite 475 precipitated on Roseobacter sp. colonies within three days of inoculation, and on $T$. 476 crunogena colonies after four days. Barite precipitated on other sulfide-oxidizing strains 
477 as well, but precipitate formation was slower than with Roseobacter sp. or T. crunogena.

478 The observation that barite precipitation occurred most rapidly on Roseobacter and $T$.

479 crunogena colonies may be explained by the fact that both of these organisms possess a

480 complete Sox sulfur oxidation pathway, including those genes that code for the SoxCD

481 subunits (Scott et al., 2006). These organisms oxidize thiosulfate directly to sulfuric acid

482 without producing elemental sulfur intermediates (Meyer et al., 2007).

483 Like Beggiatoa, S. thiotaurini has an incomplete Sox sulfide oxidation pathway,

484 which results in the production of elemental sulfur. Sulfur bacteria with incomplete Sox

485 pathways, such as Beggiatoa and S. thiotaurini, require other pathways, such as the 486 pathway that uses reverse dissimilatory sulfate reductase (rDsr), in addition to a partial 487 Sox pathway, to oxidize elemental sulfur to sulfite and ultimately sulfate (Mußmann et 488 al., 2003). Because S. thiotaurini produces elemental sulfur intermediates before it 489 produces sulfate, we might predict that sulfate production, and concomitant barite 490 precipitation, would be slower with S. thiotaurini, and indeed barite precipitation did not 491 occur until the tenth day of the experiment with strain S. thiotaurini.

492 In Halomonas sp., tetrathionate, rather than sulfate, is the primary end product of 493 thiosulfate oxidation (Sorokin et al., 1999; Podgorsek \& Imhoff, 1999). Halomonas sp. 494 colonies did not exhibit barite precipitation until 45 days after inoculation. PFA-fixed 495 control cells did not exhibit barite precipitates in any of these strains, suggesting that 496 thiosulfate oxidation in these experiment was responsible for sulfate production and 497 barite precipitation. Precipitates were found in association with the organoheterotroph 498 Maribacter sp., but instead of the barite precipitating on colony biomass, as it had with 499 the sulfide-oxidizing strains, barites associated with Maribacter sp. occurred only as 
500 halos that formed $>5 \mathrm{~mm}$ away from the colony biomass. Mineral precipitates were never

501 observed on Maribacter colony biomass. Similar halo production has previously been

502 reported in several Vibrio species grown on sulfate-containing agar medium and is

503 thought to result from sulfatase activity (Kitaura et al., 1983). Additionally agar-

504 degrading bacteria have the potential to form pits in agar-based media. Members of the

505 Bacteroidetes, especially members of the Flavobacteria, are known to degrade agar.

506 These organisms can potentially hydrolyze carrageenan, which is a sulfated

507 polysaccharide found in the red algae from which the agar is derived (Michel et al.,

508 2006). If carrageenans in the agar were hydrolyzed by Maribacter, bound sulfate would

509 be released, which could explain the halo-shaped barite precipitates observed in the

510 organoheterotroph control experiments. But importantly, barite did not precipitate on the

511 cell biomass as it did with all tested cultures of sulfide-oxidizing bacteria. Our

512 interpretations of microbial physiology as it relates to barite precipitation are supported

513 by our observations of $\mathrm{pH}$ changes reflected in the color change of phenol red.

514 The results of the precipitation experiments demonstrate that under sulfate-depleted

515 conditions, the oxidation of reduced sulfur compounds such as hydrogen sulfide and

516 thiosulfate can result in the rapid precipitation of barite that is localized on cell biomass.

517 In some cases, barite precipitation was rapid enough to entomb cells (Fig. 1G). The brine

518 fluids from Dead Crab Lake are enriched with barium, but lack sulfate (Joye et al., In

519 Preparation). Feng and Roberts (2011) also note that the precipitation of barite can locally

520 deplete sulfate, creating a zone of depletion that may provide opportunities for sulfide

521 oxidation to contribute sulfate to barite formation. At Dead Crab Lake, extensive mats of

522 Beggiatoa occupy the interface between seawater and brine fluids. Our experimental 
523 results suggest that if brine fluids encountered sulfide diffusing from microbial sulfate

524 reduction in subjacent sediments, then the production of sulfate from sulfide-oxidation

525 has the potential to trigger rapid barite precipitation and encrustation of Beggiatoa

526 biomass as recorded by the barite-mineralized filaments. Additionally, the precipitation

527 of extensive barite precipitates on non-filamentous bacteria in our precipitation

528 experiments, and the recovery of DNA from non-filamentous sulfur bacteria from the

529 barite crusts, leaves open the possibility that amorphous barite precipitates formed on

530 non-filamentous bacteria, but unlike the mineralized filaments, there is no specific

531 morphological evidence that this occurred.

\section{Did sulfur oxidation play a role in the formation of Gulf of Mexico barite crusts?}

534 Paired $\delta^{34} \mathrm{~S}$ and $\delta^{18} \mathrm{O}$ analysis provide a record of the source and diagenetic history of

535 sulfate incorporated into sedimentary barites. Isotope fractionations produced during

536 enzymatic reactions within sulfate-reducing bacteria tend to generate residual pools of

$537{ }^{34}$ S-enriched and ${ }^{18} \mathrm{O}$-enriched sulfate, although the isotope effects are different for sulfur

538 and oxygen (Brunner et al., 2005; Bradley et al., 2011). The isotopic offset between

539 sulfate and sulfide that is produced during dissimilatory sulfate reduction can be large in

540 magnitude (up to $66 \%$ ), and tends to decrease when sulfate reduction rates are elevated

541 (Sim et al., 2011; Leavitt et al., 2013), or when sulfate concentration is limiting (Habicht

542 et al., 2002). In batch experiments, rate-dependent sulfur isotope fractionations appear to

543 be largely controlled by electron donor supply (Leavitt et al., 2013), and in natural

544 systems, higher sulfate reduction rates are associated with lower isotope fractionations as

545 measured in oil and gas seeps of the Gulf of Mexico (Aharon and Fu, 2000). Residual 
546 sulfate-oxygen isotope values also increase as a function of sulfate reduction; however,

547 the overall effect is governed by equilibrium oxygen isotope exchange between

548 intracellular sulfoxy ions and ambient water (Brunner et al., 2005; Wankel et al., 2014).

549 In addition to the pathway of dissimilatory sulfate reduction, consortia of methanotrophic

550 archaea and sulfate-reducing bacteria can couple anaerobic oxidation of methane to

551 sulfate reduction (AOM-SR) in sedimentary environments where sulfate and methane

552 gradients overlap (Boetius et al., 2000; Orphan et al., 2001; Joye et al., 2004; Orcutt et

553 al., 2005; Milucka et al., 2012). The sulfur and oxygen isotope fractionations during

554 AOM-SR are similar in magnitude to sulfate reduction and tend to decrease in methane

555 charged gas seeps (Deusner et al., 2014).

556 Regardless of the microbiota or their biochemical pathways, barites that form within the 557 zone of sulfate reduction at hydrocarbon seeps tend to record a trend of increasing $\delta^{34} \mathrm{~S}$

558 and $\delta^{18} \mathrm{O}$ sulfate values such as those expected from microbial sulfate reduction (Aharon

559 \& Fu, 2000; Feng \& Roberts, 2011). The authigenic barites studied here were enriched in

$560{ }^{34} \mathrm{~S}$ and ${ }^{18} \mathrm{O}$ relative to contemporaneous seawater (Fig. 4); however, authigenic barites

561 from other methane seeps generally have comparatively higher $\delta^{34} \mathrm{~S}$ and $\delta^{18} \mathrm{O}$ values

562 (Feng \& Roberts 2011). Feng and Roberts (2011) proposed that barite crusts with higher

$563 \delta^{34} \mathrm{~S}$ and $\delta^{18} \mathrm{O}$ values formed beneath the sediment/water interface under conditions

564 where barium fluxes are relatively low, and efficient bacterial sulfate reduction can drive

565 residual pore water fluids toward greater enrichment in ${ }^{34} \mathrm{~S}$ and ${ }^{18} \mathrm{O}$. Conversely, barites

566 that precipitate at the sediment/water interface have $\delta^{34} \mathrm{~S}$ and $\delta^{18} \mathrm{O}$ values closer to

567 seawater values, but slightly enriched in ${ }^{34} \mathrm{~S}$ and ${ }^{18} \mathrm{O}$, similar to that observed here, a

568 correlation that has been attributed to less efficient sulfate reduction in a more open 
569 system (Feng and Roberts, 2011). This interpretation explains at least some of the

570 disparity in isotope values seen in barites that formed at, or above, the sediment/water

571 interface relative to those that precipitated in the sediments.

572 In the case of the barite samples studied here, molecular evidence suggests a close 573 spatial association between sulfate-reducing bacteria and sulfide-oxidizing bacteria. We

574 suggest that one additional aspect of the more geochemically-open system near the 575 sediment/water interface is the presence of sulfide-oxidizing bacterial mats that can 576 shuttle sulfide to sulfate during sulfur oxidation. The relatively small sulfur isotope 577 effects ( $\pm 5 \%$ ) that occur during biological sulfide oxidation (Fry et al., 1986; Zerkle et 578 al., 2009; Brabec et al., 2012), would produce sulfate with low $\delta^{34} S$ values that, when 579 mixed with the local pool of dissolved sulfate in the microenvironment from which the 580 barite precipitated, can result in barite with muted ${ }^{34} \mathrm{~S}$-enrichments. Oxygen isotope 581 exchange during sulfide oxidation can also contribute to low $\delta^{18} \mathrm{O}$ values. The oxidation 582 effects are likely buffered by co-precipitation of contemporaneous seawater sulfate in the 583 barite crusts studied here. The presence of molecular signatures indicating a close 584 association between sulfate-reducing bacteria and sulfide-oxidizing bacteria, and the 585 precipitation of barite directly on mats of sulfide-oxidizing bacteria within the barite 586 crusts, provide evidence for an active oxidative sulfur cycle. This microenvironment 587 fosters barite precipitation where sulfide oxidation potentially contributed, at least in part, 588 to the precipitation of barite on cell biomass, leading to mineral entombment of the kind 589 that is observed in samples from Dead Crab Lake brine pool. The localization of barite 590 precipitates on filaments of sulfide-oxidizing bacteria, as opposed to other benthic 591 substrates such as rocks, shells or sediment grains, also supports the idea that sulfide 
592 oxidation may have played a role in the encrustation of the filaments by barite. We

593 suggest that the barite crusts observed in this study, which are slightly enriched in ${ }^{34} \mathrm{~S}$ and

$594{ }^{18} \mathrm{O}$ relative to seawater, formed at an interface in which both seawater sulfate and

595 sulfide-oxidation supplied sulfate for the precipitation of barite.

597 CONCLUSIONS

598 Chemolithotrophic microbes commonly colonize interfaces between geochemical 599 zones, such as the gradients conditions between reduced sulfur and oxygen, or reduced

600 iron and oxygen. At these geochemical interfaces, abiotic oxidation reactions that are 601 thermodynamic favorability may be kinetically slow (Gartman et al., 2011). The 602 metabolic activity of lithotrophic organisms, along with the potential of cells to serve as 603 nucleation sites, can increase the rate of precipitation of minerals at such interfaces, and 604 influence the physical and chemical characteristics of any precipitates that may form. 605 Mats of sulfide-oxidizing bacteria colonize steep geochemical interfaces separating 606 anoxic, sulfidic, barium-rich fluids, and oxic, sulfate-rich bottom waters, at brine pools in 607 the Gulf of Mexico. These sediments are provided with hydrogen sulfide produced by 608 dissimilatory sulfate reduction in surrounding sediments. If microbes were not present at 609 this interface, barite would (and does) precipitate as barium-rich fluids encounter 610 seawater that contains sulfate (Fu et al., 1994; Torres et. al. 1996; Aquilina et al., 1997;

611 Castellini et al., 2006; Roberts et al., 2010). However, mats of sulfide-oxidizing bacteria

612 can also generate sulfate through the oxidation of sulfide and/or provide substrates for 613 mineral nucleation in this zone. The mineralized filaments described here precipitated 614 under conditions that were not directly observed, and the isotopic composition of the 
615 barite-encrusted filaments do not, by themselves, provide unambiguous evidence of

616 sulfide oxidation contributing to barite precipitation. However, the isotopic values are

617 fully consistent with a depositional environment in which sulfide oxidation is occurring

618 and contributing sulfate to barite precipitation. Laboratory experiments show that sulfate

619 evolved from sulfide oxidation in simulated brine fluids leads to rapid barite precipitation

620 on cell biomass, encrusting sulfide-oxidizing bacteria in a manner reminiscent of the

621 encrustation on Beggiatoa observed in the Gulf of Mexico barite crusts studied here. Our

622 observations suggest that bacterial sulfide oxidation may be involved in barite

623 precipitation under certain marine conditions, via the production of sulfate in a manner

624 similar to that already known to occur in non-marine environments (e.g., Senko et al.,

625 2004; Bonny \& Jones, 2008a). The expansion of the environments in which bacterial

626 sulfide oxidation is suspected to facilitate barite precipitation introduces new possibilities

627 for the origins of certain ancient barite deposits. Additionally, the discovery of barite

628 mineralization of Beggiatoa in modern marine sediments extends the fossilization

629 potential of these organisms beyond their currently known preservation in carbonates and

630 phosphorites, and opens up the possibility that they are preserved in ancient marine barite 631 deposits as well.

632

\section{ACKNOWLEDGEMENTS}

635 We thank the crew, SSG, and science team of research cruise AT18-2 (upon which these 636 samples were collected) onboard the R/V Atlantis with the HOV Alvin, funded by the

637 National Science Foundation (EF-0801741 to SBJ). Portions of this work were supported 
639 funded by a Howard Hughes Medical Institute internship, isolated the Gulf of Mexico

640 strains used in the mineral precipitation experiments. Elizabeth Ricci performed PCRs

641 that allowed for strain identification. This work was carried out in part using resources at

642 the University of Minnesota Characterization Facility, which receives partial support

643 from NSF through the MRSEC program, the University of Minnesota Supercomputing

644 Institute, and University of Minnesota Genomics Center.

645

646

647

648

649

650

651

652

653

654

655

656

657

658

659

660

661
FIGURES

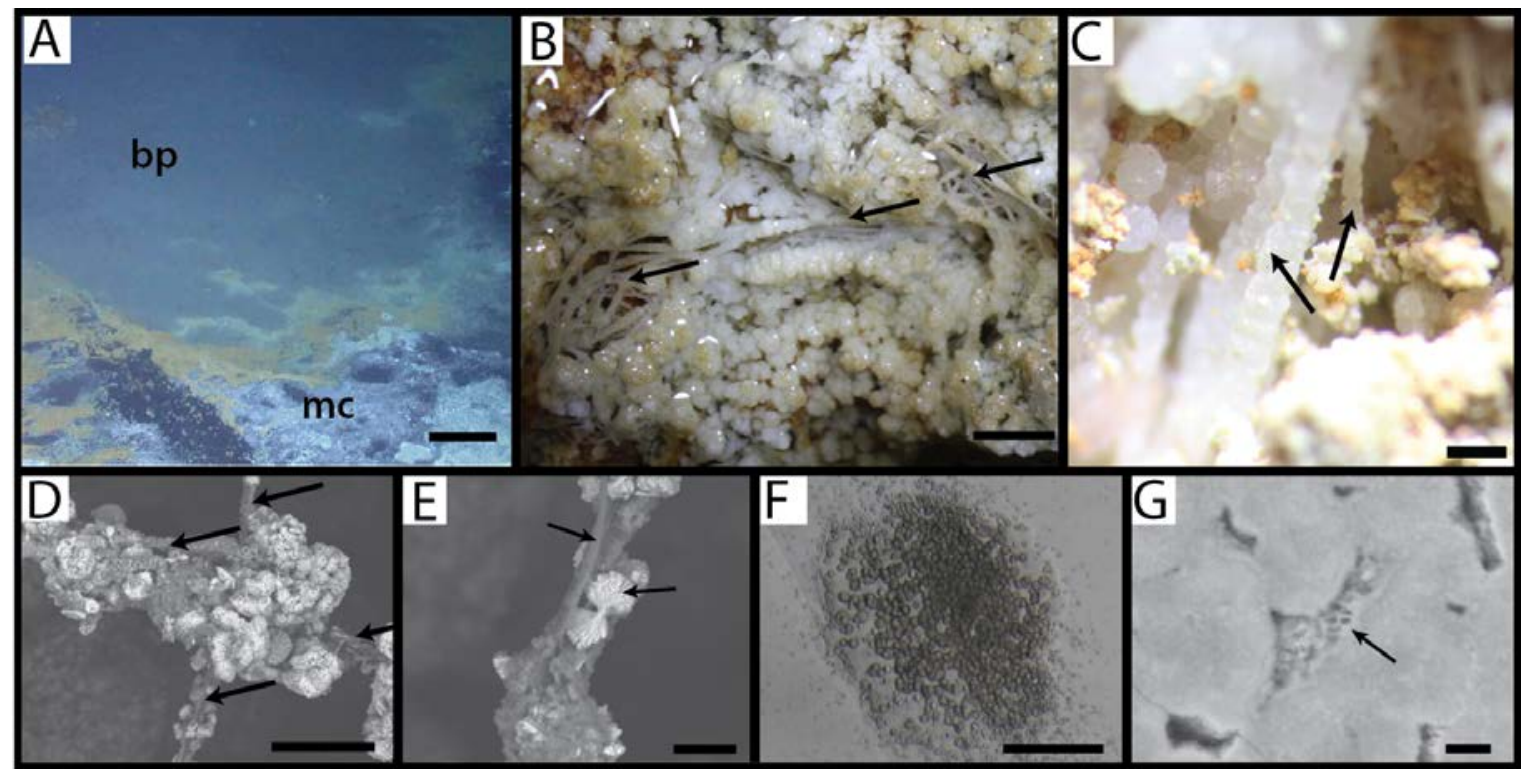

Fig. 1: A) Dead Crab Lake, a brine pool (bp) in the Gulf of Mexico, is surrounded by a complex assemblage of multi-colored mineral crusts (mc) and microbial mats containing abundant Beggiatoa. B) Networks of mineralized filaments (arrows) are found within barite crusts. The filament network is surrounded by barite precipitates that have a massive, non-filamentous habit. C) Detail showing barite mineral filaments that exhibit apparent septations that, if biological in origin, resemble those of Beggiatoa filaments. D, E) Scanning electron microscope images of bacterial filaments from Dead Crab Lake partially encrusted in barite. F) Light microscope images of barite experimentally precipitated on Roseobacter colony. G) Scanning electron micrographs showing morphologies of experimental barite precipitates. Arrows indicate areas of probable bacterial cells entombed within barite precipitates. Other bacterial experiments show similar encrustation of colony biomass. Scale bar in $A=\sim 30 \mathrm{~cm} \mathrm{~B}=1 \mathrm{~mm}, \mathrm{C}=100 \mu \mathrm{m}$, $\mathrm{D}=40 \mu \mathrm{m}, \mathrm{E}=10 \mu \mathrm{m} ; \mathrm{F}=100 \mu \mathrm{m}, \mathrm{G}=3 \mu \mathrm{m}$. 

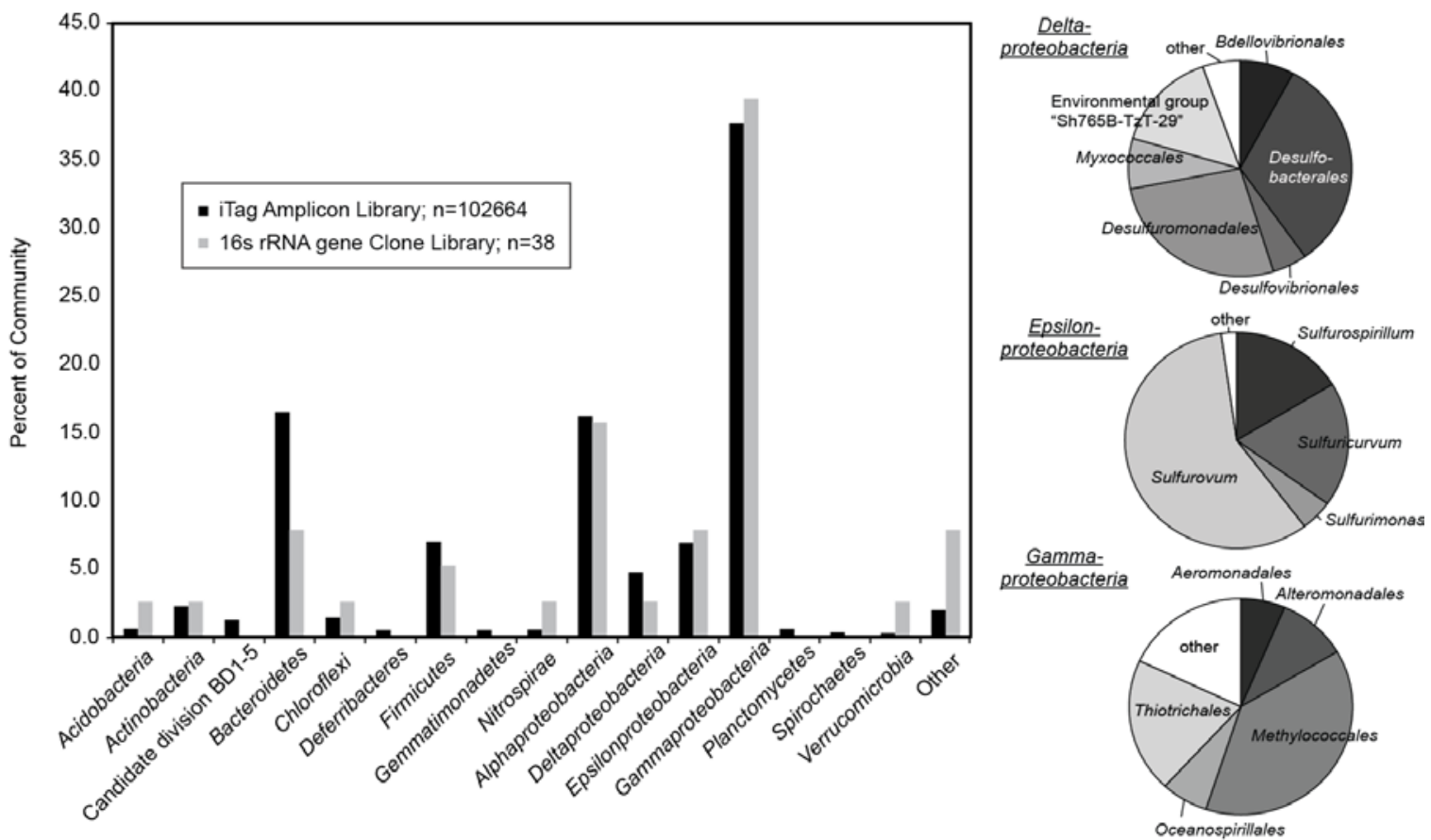

Fig. 2: Taxonomic composition of the bacterial 16S rRNA gene clone library and the 16S rRNA gene iTag amplicon library from a single filament-hosting barite crust sample. Pie charts at right summarizing a subset of the iTag results show the composition at the order level for deltaproteobacteria and gammaproteobacteria, and at the genus level for epsilonproteobacteria. Both libraries were generated from the same DNA extraction. 


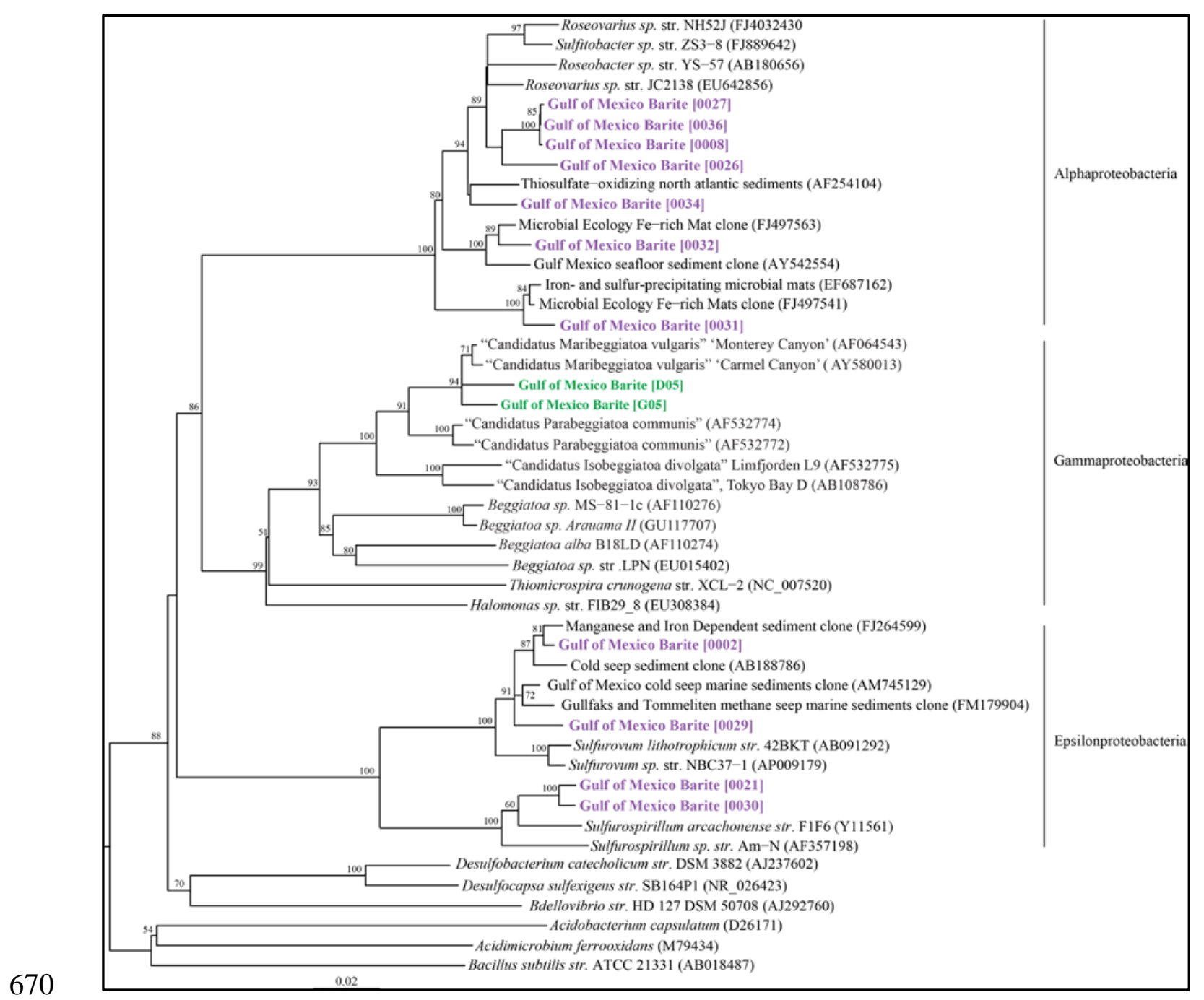

Fig. 3: Neighbor joining phylogram of $16 \mathrm{~S}$ rRNA gene sequences from the barite crust 673 bacterial clone library showing putative sulfide-oxidizing bacteria. Sequences generated 674 from general bacterial primers are highlighted in purple, while sequences produced with 675 Beggiatoaceae-specific primers are shown in green. Bootstrap values greater than 50 are 676 shown for each node. 


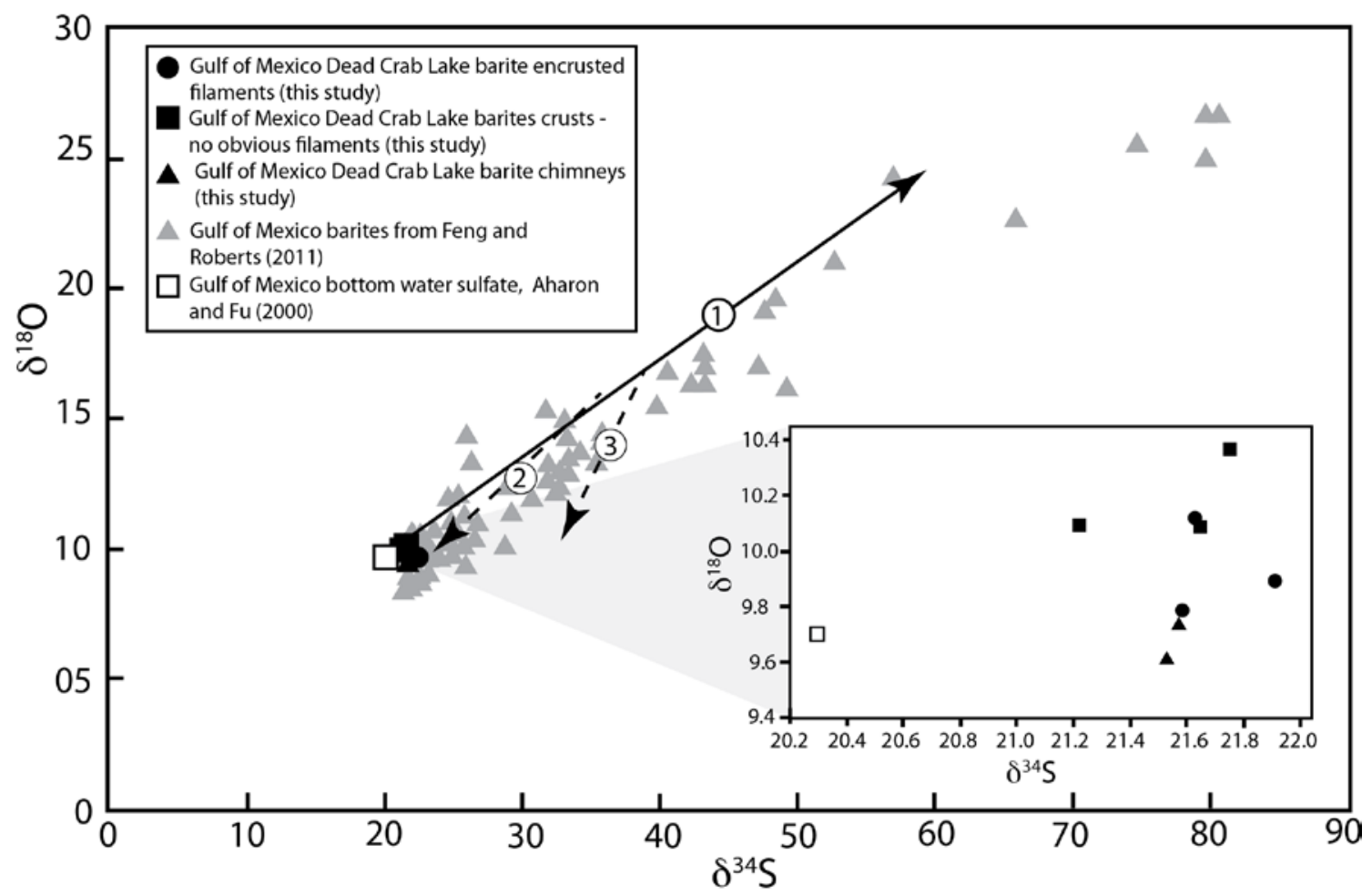

679 Fig. 4: $\delta^{18} \mathrm{O}$ and $\delta^{34} \mathrm{~S}$ of sulfates and barites in the Gulf of Mexico including those reported on by Feng and Roberts (2011) (gray triangles), and those in this study that include barite mineralized filaments and surrounding barite cements, show enrichment in ${ }^{18} \mathrm{O}$ and ${ }^{34} \mathrm{~S}$. This enrichment tracks the isotopic evolution of sedimentary pore waters influenced to varying degrees by microbial sulfate reduction, the trajectory of which is shown by Arrow 1. Inset shows detail of samples from this study relative to seawater sulfate. Barites that are less enriched in ${ }^{18} \mathrm{O}$ and ${ }^{34} \mathrm{~S}$ may result from lower rates of sulfate reduction, a more open system that allows for the incorporation of seawater sulfate, and/or the incorporation of sulfate produced by sulfide oxidation. Trajectories shown by Arrows 2 and 3 show varying degrees of potential oxygen isotope exchange with ambient pore water and seawater.

690

691

\section{SUPPLEMENT}

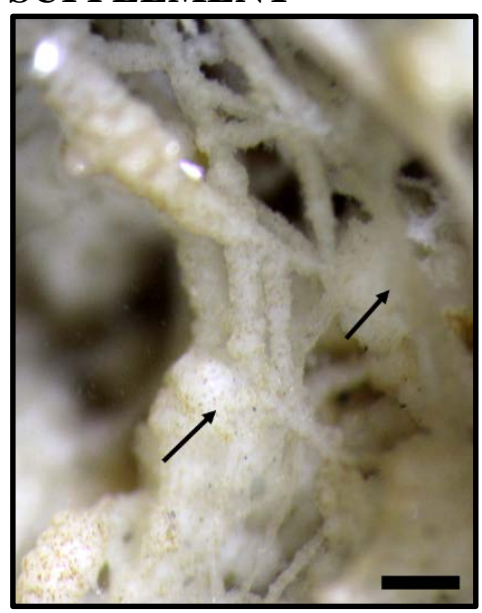


693 Fig. S1. Where accumulations of barite-mineralized filaments attain sufficient density, an 694 amorphous globular barite crystal mass can result. These massive textures resemble the 695 precipitates that make up the bulk of the barite crusts. Scale bar $=100 \mu \mathrm{m}$.

696

697

698

699

700

701

702

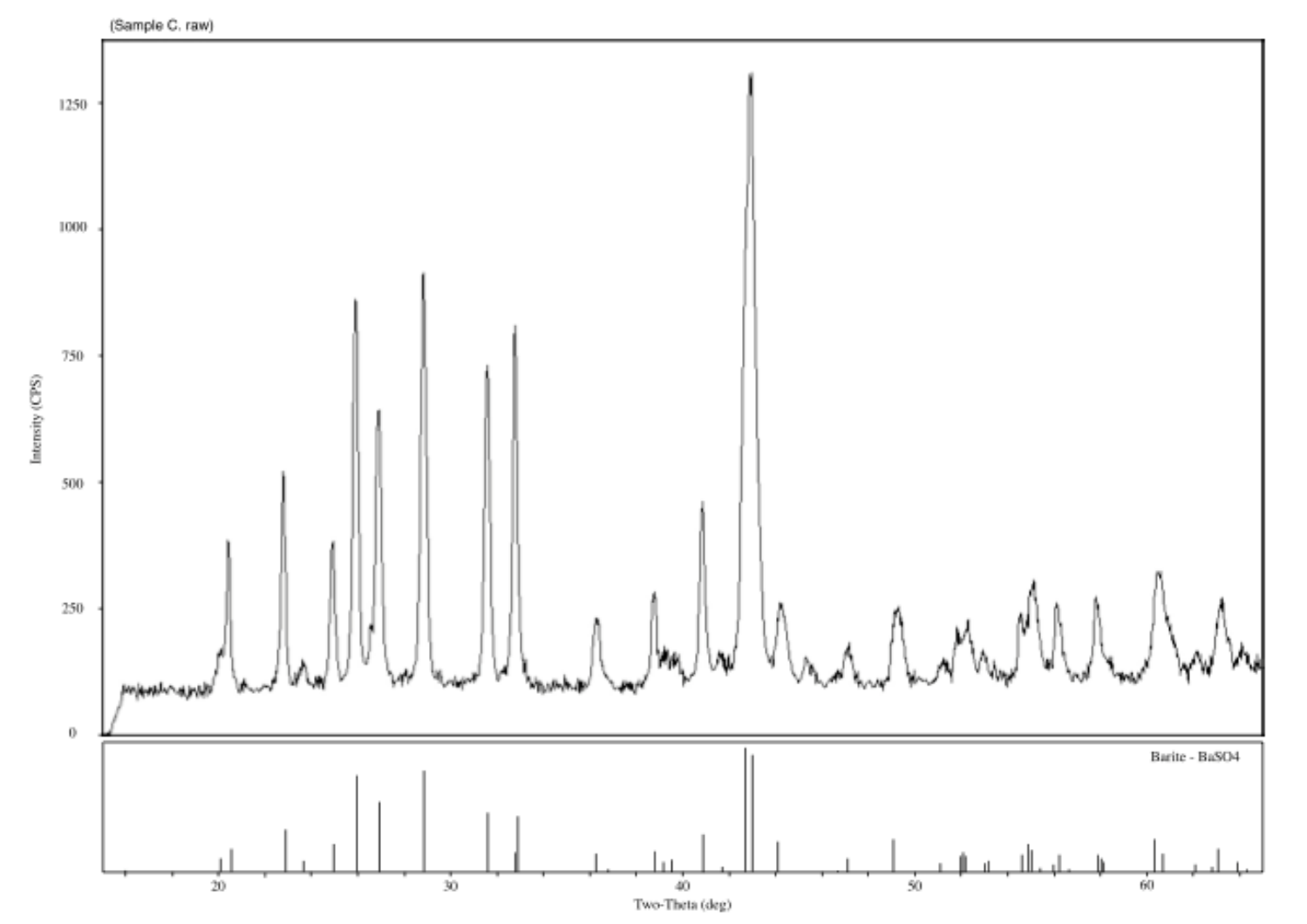

Fig. S2. X-ray diffraction diagram of precipitates found in GOM mineral crust. Typical barite $\left(\mathrm{BaSO}_{4}\right)$ peaks are indicated at bottom for comparison. A minor quartz $\left(\mathrm{SiO}_{2}\right)$ peak is visible at $\sim 2 \theta 26.5^{\circ}$ and an unidentified peak is visible at $\sim 2 \theta 45^{\circ}$. 


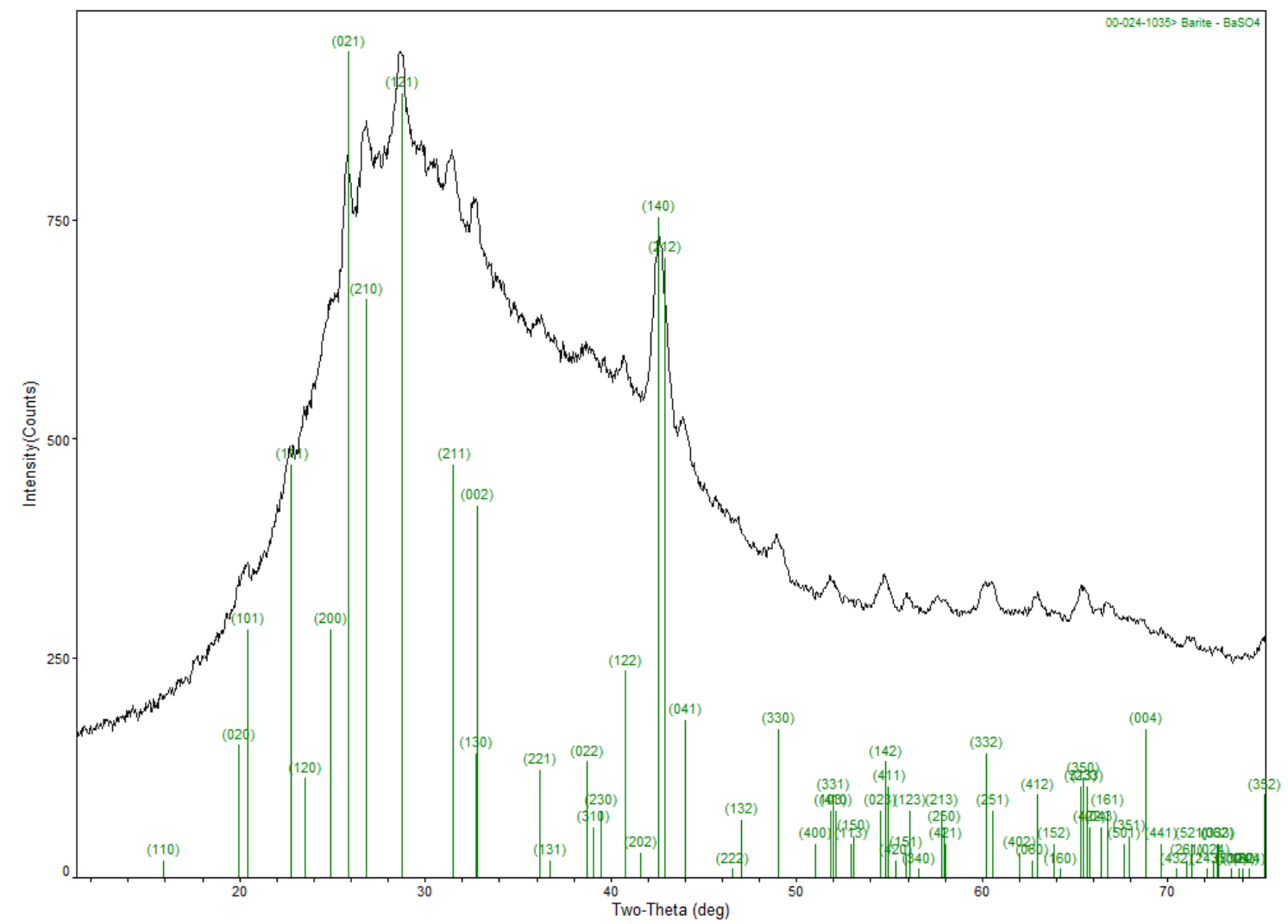

Fig. S3. Representative micro XRD diffractogram of precipitates found in laboratory precipitation experiments with Roseobacter. Precipitates associated with other strains

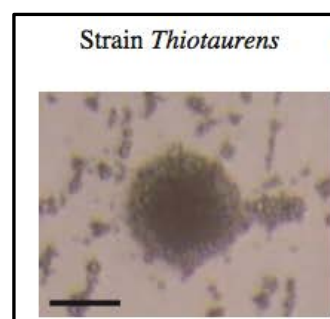

Thiomicrospira crunogena

Roseobacter

Maribacter

Halomonas
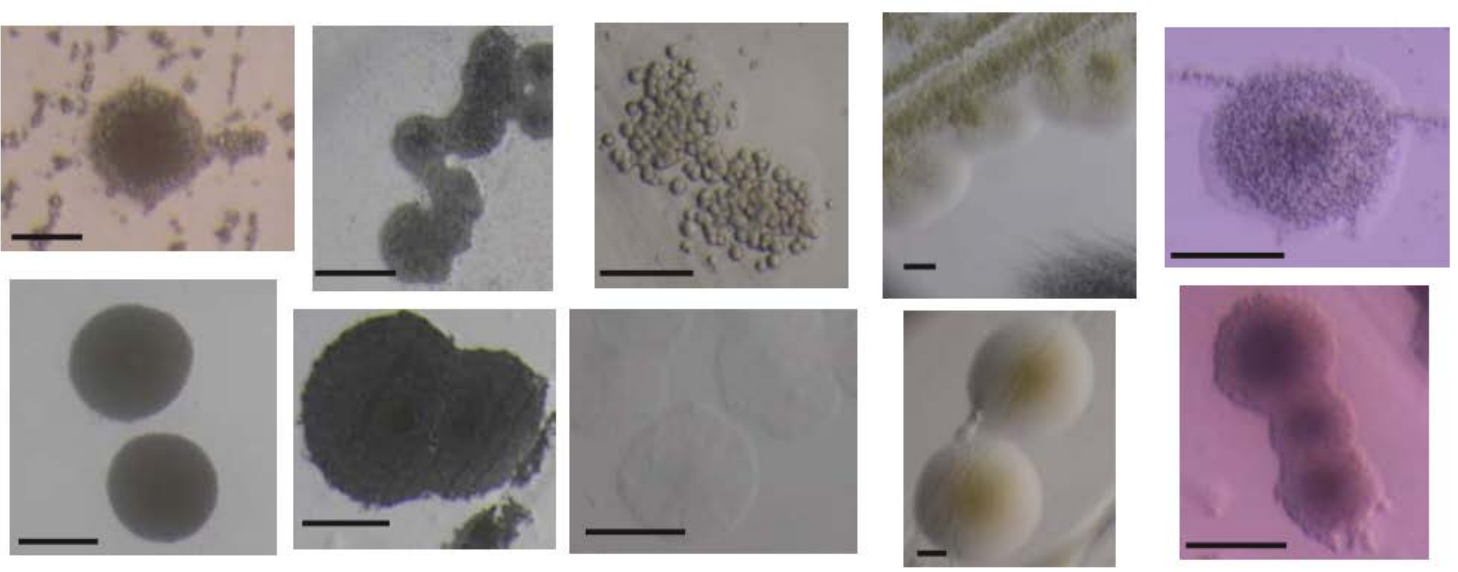

Fig. S4. Reflected light images of colonies from barite precipitation experiments. Images show precipitation results of microbial growth on media of $10 \mathrm{mM} \mathrm{Na}_{2} \mathrm{~S}_{2} \mathrm{O}_{3}$ with $2 \mathrm{mM}$ $\mathrm{BaCl}$ (above) and without $2 \mathrm{mM} \mathrm{BaCl}$ (below). Scale bars $=100 \mu \mathrm{m}$. 
Table S1. Primer sequences used for clone libraries, iTag and isolate screening. Illumina amplicon V3_7R contains a barcode region (shaded) used to distinguish the sample from 717 a pooled dataset.

\begin{tabular}{|l|l|l|}
\hline Primer & Sequence & Reference \\
\hline EUB 27F & AGAGTTTGATCMTGGCTCAG & Lane, 1991 \\
\hline EUB 1492R & GGTTACCTTGTTACGACTT & Lane, 1991 \\
\hline EUB primer 341F & CCTACGGGAGGCAGCAG & Salman et al., 2011 \\
\hline VSOXBr & GGATYAATYTCCCCCAACAT & $\begin{array}{l}\text { Kalanetra et al., } \\
2005\end{array}$ \\
\hline V3_7R & $\begin{array}{l}\text { caagcagaagacggcatacgagatGATCTGgtgactggagttcagacgtgtgc } \\
\text { tcttccgatctATTACCGCGGCTGCTGG }\end{array}$ & $\begin{array}{l}\text { Bartram et al., } \\
2011\end{array}$ \\
\hline V3_F modified2 & $\begin{array}{l}\text { aatgatacggcgaccaccgagatctacactctttccctacacgacgctcttccgatct } \\
\text { NNNNCCTACGGGAGGCAGCAG }\end{array}$ & $\begin{array}{l}\text { Bartram et al., } \\
2011\end{array}$ \\
\hline soxB693F & ATCGGNCARGCNTTYCCNTA & Petri et al., 2001 \\
\hline soxB1164B & AARTTNCCNCGNCGRTA & Petri et al., 2001 \\
\hline
\end{tabular}

Table S2.

\begin{tabular}{|l|l|l|l|l|}
\hline Location & $\begin{array}{l}\text { Sample } \\
\text { type }\end{array}$ & $\begin{array}{l}\text { Primary XRD } \\
\text { mineral composition }\end{array}$ & $\begin{array}{l}\delta^{34} S_{\text {Barite }} \\
(\% \text { V-CDT })\end{array}$ & $\begin{array}{l}\delta^{18} \mathrm{O}_{\text {Barite }} \\
(\% \text { V-SMOW })\end{array}$ \\
\hline GC246 & Chimney & Barite & 21.6 & 9.7 \\
\hline GC246 & Chimney & Barite & 21.5 & 9.6 \\
\hline GC246 & Crust & Barite & 21.2 & 10.1 \\
\hline GC246 & Crust & Barite & 21.8 & 10.4 \\
\hline GC246 & Crust & Barite & 21.6 & 10.1 \\
\hline GC246 & Filaments & Barite & 21.9 & 9.9 \\
\hline GC246 & Filaments & Barite & 21.6 & 10.1 \\
\hline GC246 & Filaments & Barite & 21.6 & 9.8 \\
\hline
\end{tabular}

721

\section{REFERENCES}

Addy SK, Behrens EW (1980) Time of accumulation of hypersaline anoxic brine in Orca basin (Gulf of Mexico). Marine Geology, 37, 241-252.

Aharon P, Fu B (2000) Microbial sulfate reduction rates and sulfur and oxygen isotope fractionations at oil and gas seeps in deepwater Gulf of Mexico. Geochimica et Cosmochimica Acta, 64, 233-246.

Aloisi G, Wallmann K, Bollwerk SM, Derkachev A, Bohrmann G, Suess E (2004) The effect of dissolved barium on biogeochemical processes at cold seeps. Geochimica et Cosmochimica Acta, 68, 1735-1748.

Aquilina L, Dia AN, Boulègue J, Bourgois J, Fouillac AM (1997) Massive barite deposits in the convergent margin off Peru: Implications for fluid circulation within subduction zones. Geochimica et Cosmochimica Acta, 61, 1233-1245.

Arenas C, Gutierrex F, Osacar C, Sancho C (2000) Sedimentology and geochemistry of fluvio-lacustrine tufa deposits controlled by evaporite solution subsidence in the central Ebro Depression, NE Spain. Sedimentology, 47, 883-909.

Aronesty E (2011) ea-utils: Command-line tools for processing biological sequencing data. In: Expression Analysis, Durham, NC. 
Bailey JV, Corsetti FA, Greene SE, Crosby CH, Liu P, Orphan VJ (2013) Filamentous sulfur bacteria preserved in modern and ancient phosphatic sediments: implications for the role of oxygen and bacteria in phosphogenesis. Geobiology, 11, 397-405.

Barbieri R, Cavalazzi B (2005) Microbial fabrics from Neogene cold seep carbonates, Northern Apeninne, Italy. Palaeogeography Palaeoclimatology Palaeoecology, 227, 143-155.

Bartram AK, Lynch MD, Stearns JC, Moreno-Hagelsieb G, Neufeld JD (2011) Generation of multimillion-sequence 16S rRNA gene libraries from complex microbial communities by assembling paired-end Illumina reads. Applied and Environmental Microbiology, 77, 3846-3852.

Bertram MA, James PC (1997) Morphological and compositional evidence for biotic precipitation of marine barite. Journal of Marine Research, 55, 577-593.

Bishop JKB (1988a) The barite-opal-organic carbon association in oceanic particulate matter. Nature, 311, 341-343.

Blankenberg D, Kuster GV, Coraor N, Ananda G, Lazarus R, Mangan M, Nekrutenko A, Taylor J (2010) Galaxy: A Web Based Genome Analysis Tool for Experimentalists. Current protocols in molecular biology, 19.10. 11-19.10. 21.

Boetius A, Ravenschlag K, Schubert CJ, Rickert D, Widdel F, Gieseke A, Amann R, Jorgensen BB, Witte U, Pfannkuche O (2000) A marine microbial consortium apparently mediating anaerobic oxidation of methane. Nature, 407, 623-626.

Bojanowski MJ (2007) Oligocene cold-seep carbonates from the Carpathians and their inferred relation to gas hydrates. Facies, 53, 347-360.

Bonny SM, Jones B (2007a) Barite $\left(\mathrm{BaSO}_{4}\right)$ biomineralization at Flybye Springs, a cold sulphur spring system in Canada's Northwest Territories. Canadian Journal of Earth Sciences, 44, 835-856.

Bonny SM, Jones B (2007b) Diatom-mediated barite precipitation in microbial mats calcifying at Stinking Springs, a warm sulphur spring system in Northwestern Utah, USA. Sedimentary Geology, 194, 223-244.

Bonny SM, Jones B (2008a) Controls on the precipitation of barite $\left(\mathrm{BaSO}_{4}\right)$ crystals in calcite travertine at Twitya Spring, a warm sulphur spring in Canada's Northwest Territories. Sedimentary Geology, 203, 36-53.

Bonny SM, Jones B (2008b) Experimental precipitation of barite (BaSO4) among streamers of sulfur-oxidizing bacteria. Journal of Sedimentary Research, 78, 357365.

Brabec MY, Lyons TW, Mandernack KW (2012) Oxygen and sulfur isotope fractionation during sulfide oxidation by anoxygenic phototrophic bacteria. Geochimica et Cosmochimica Acta, 83, 234-251.

Bradley AS, Leavitt WD, Johnston DT (2011) Revisiting the dissimilatory sulfate reduction pathway. Geobiology, 9, 446-457.

Bromberg C, Cash H, Curtis P, Goebel III C, Irwin L, Singer J, Van Hoewyk D, Winkelplek J (1995) Sequencher. Gene Codes Corporation. Ann Arbor, Michigan.

Brunner B, Bernasconi SM, Kleikemper J, Schroth MH (2005) A model for oxygen and sulfur isotope fractionation in sulfate during bacterial sulfate reduction processes. Geochimica et Cosmochimica Acta, 69, 4773-4785. 
Buchan A, Gonzalez JM, Moran MA (2005) Overview of the marine Roseobacter lineage. Applied and Environmental Microbiology, 71, 5665-5677.

Campbell BJ, Engel AS, Porter ML, Takai K (2006) The versatile epsilonproteobacteria: key players in sulphidic habitats. Nature Reviews Microbiology, 4, 458-468.

Castellini, D. G., et al. (2006). Barium cycling in shallow sediment above active mud volcanoes in the Gulf of Mexico. Chemical Geology, 226, 1-30.

Cavagna S, Clari P, Martire L (1999) The role of bacteria in the formation of cold seep carbonates: geological evidence from Monferrato (Tertiary, NW Italy). Sedimentary Geology, 126, 253-270.

Chow TJ, Goldberg ED (1960) On the marine geochemistry of barium. Geochimica et Cosmochimica Acta, 20, 192-198.

Church TM, Wolgemuth K (1972) Marine barite saturation. Earth and Planetary Science Letters, 15, 35-44.

Contreras S, Meister P, Liu B, Prieto-Mollar X, Hinrichs KU, Khalili A, Ferdelman TG, Kuypers MM, Jorgensen BB (2013) Cyclic 100-ka (glacial-interglacial) migration of subseafloor redox zonation on the Peruvian shelf. Proceedings of the National Acadeny of Sciiences U S A, 110, 18098-18103.

Daffonchio D, Borin S, Brusa T, Brusetti L, Van Der Wielen PWJJ, Bolhuis H, Yakimov MM, D'auria G, Giuliano L, Marty D, Tamburini C, Mcgenity TJ, Hallsworth JE, Sass AM, Timmis KN, Tselepides A, De Lange GJ, Hübner A, Thomson J, Varnavas SP, Gasparoni F, Gerber HW, Malinverno E, Corselli C (2006) Stratified prokaryote network in the oxic-anoxic transition of a deep-sea halocline. Nature, 440, 203-207.

Dehairs F, Chesselet R, Jedwab J (1980) Discrete suspended particles of barite and the barium cycle in the open ocean. Earth and Planetary Science Letters, 49, 528550.

Dehairs F, Stroobants N, Goeyens L (1991) Suspended barite as a tracer of biological activity in the Southern Ocean. Marine Chemistry, 35, 399-410.

Desantis TZ, Hugenholtz P, Larsen N, Rojas M, Brodie EL, Keller K, Huber T, Dalevi D, Hu P, Andersen GL (2006) Greengenes, a chimera-checked 16S rRNA gene database and workbench compatible with ARB. Applied and Environmental Microbiology, 72, 5069-5072.

Deusner C, Holler T, Arnold GL, Bernasconi SM, Formolo MJ, Brunner B (2014) Sulfur and oxygen isotope fractionation during sulfate reduction coupled to anaerobic oxidation of methane is dependent on methane concentration. Earth and Planetary Science Letters, 399, 61-73.

Dymond J, Suess E, Lyle M (1992) Barium in deep sea sediments: A geochemical proxy for paleoproductivity. Paleoceanography, 163, 181.

Eder W, Ludwig W, Huber R (1999) Novel 16S rRNA gene sequences retrieved from highly saline brine sediments of Kebrit Deep, Red Sea. Archives of Microbiology, 172, 213-218.

Edgar RC, Haas BJ, Clemente JC, Quince C, Knight R (2011) UCHIME improves sensitivity and speed of chimera detection. Bioinformatics, 27, 2194-2200.

Eickmann B, Thorseth IH, Peters M, Strauss H, Bröcker M, Pedersen RB (2014) Barite in hydrothermal environments as a recorder of subseafloor processes: a multipleisotope study from the Loki's Castle vent field. Geobiology, 12, 308-321. 
Feng D, Roberts HH (2011) Geochemical characteristics of the barite deposits at cold seeps from the northern Gulf of Mexico continental slope. Earth and Planetary Science Letters, 309, 89-99.

Flood, B, Bailey, J, Jones, D (2015) Sedimenticola thiotaurini sp. nov., a sulfide-oxidizing bacterium isolated from saltmarsh sediments, emended description of the genus Sedimenticola and holotype strain Sedimenticola selenatireducens. International Journal of Systematic and Evolutionary Microbiology. doi: 10.1099/ijs.0.000295

Fritz P, Basharmal GM, Drimmie RJ, Ibsen J, Qureshi RM (1989) Oxygen isotope exchange between sulphate and water during bacterial reduction of sulphate. Chemical Geology, 79, 9-105.

Fry B, Cox J, Gest H, Hayes JM (1986) Discrimination between ${ }^{34} \mathrm{~S}$ and ${ }^{32} \mathrm{~S}$ during bacterial metabolism of inorganic sulfur compounds. Journal of Bacteriology, 165, 328-330.

Fu, B, Aharon, P, Byerly, G, Roberts, H (1994) Barite chimneys on the Gulf of Mexico slope: initial report on their petrography and geochemistry. Geo-Marine Letters, 14, 81-87.

Ganeshram RS, Francois R, Commeau J, Brown-Leger SL (2003) An experimental investigation of barite formation in seawater. Geochimica et Cosmochimica Acta, 67, 2599-2605.

Gartman A, Yücel M, Madison A, Chu D, Ma S, Janzen C, Becker E, Beinart R, Girguis P, Luther G, III (2011) Sulfide oxidation across diffuse flow zones of hydrothermal vents. Aquatic Geochemistry, 17, 583-601.

Giardine B, Riemer C, Hardison RC, Burhans R, Elnitski L, Shah P, Zhang Y, Blankenberg D, Albert I, Taylor J (2005) Galaxy: a platform for interactive largescale genome analysis. Genome Research, 15, 1451-1455.

Gingele F, Dahmke A (1994) Discrete barite particles and barium as a tracer of paleoproductivity in South Atlantic sediments Paleoceanography, 9, 151-168.

Goldberg ED, Arrhenius G (1958) Chemistry of pelagic sediments. Geochimica et Cosmochimica Acta, 13, 153-212.

Goldberg ED, Somayajulu BLK, Gallway J, Kaplan IR, Faure G (1969) Differences between barites of marine and continental origins Geochimica et Cosmochimica Acta, 33, 287-289.

Gonzalez-Muñoz M, Martinez-Ruiz F, Morcillo F, Martin-Ramos J, Paytan A (2012) Precipitation of barite by marine bacteria: A possible mechanism for marine barite formation. Geology, 40, 675-678.

Gonzalez-Munoz MT, Fernandez-Luque, B., Martínez-Ruiz, F., Chekroun, K.B., Arias, J.M., Rodríguez-Gallego, M., Martínez-Canamero, M., Linares, C., Paytan, A., (2003) Precipitation of barite by Myxococcus xanthus: possible implications for the biogeochemical cycle of barium. Applied and Environmental Microbiology, 69, 5722-5725.

Greinert J, Bollwerk SM, Derkachev A, Bohrmann G, Suess E (2002) Massive barite deposits and carbonate mineralization in the Derugin Basin, Sea of Okhotsk: precipitation processes at cold seep sites. Earth and Planetary Science Letters, 203, 165-180. 
Griffith EM, Paytan A (2012) Barite in the ocean- occurrence, geochemistry and 3091.2012.01327.x. applications. Sedimentology, doi: 10.1111/j.1365-

Habicht KS, Gade M, Thamdrup B, Berg P, Canfield DE (2002) Calibration of sulfate levels in the Archean ocean. Science, 298, 2372-2374.

Hanor JS (2000) Barite-celestine geochemistry and environments of formation. Reviews in Mineralogy and Geochemistry, 40, 193-275.

Jannasch HW, Wirsen CO, Nelson DC, Robertson LA (1985) Thiomicrospira crunogena sp. nov., a colorless, sulfur-oxidizing bacterium from a deep-sea hydrothermal vent. International Journal of Systematic Bactreiology, 35, 422-424.

Jones, D.S.*, Flood, B.E. *, Bailey, J.V. (2015) Metatranscriptomic analysis of diminutive Thiomargarita-like bacteria (“Candidatus Thiopilula spp.”) from abyssal cold seeps of the Barbados Accretionary Prism. Applied and Environmental Microbiology. 81:3142-3156

Joye SB, Boetius A, Orcutt BN, Montoya JP, Schulz HN, Erickson MJ, Lugo SK (2004) The anaerobic oxidation of methane and sulfate reduction in sediments from Gulf of Mexico cold seeps. Chemical Geology, 205, 219-238.

Joye SB, Macdonald, I.R., Montoya, J.P., Peccini, M. (2005) Geophysical and geochemical signatures of Gulf of Mexico seafloor brines. Biogeosciences, 2, 295-309.

Kalanetra KM, Joye SB, Sunseri NR, Nelson DC (2005) Novel vacuolate sulfur bacteria from the Gulf of Mexico reproduce by reductive division in three dimensions. Environmental Microbiology, 7, 1451-1460.

Kappler U, Dahl C (2001) Enzymology and molecular biology of prokaryotic sulfite oxidation. FEMS Microbiology Letters, 203, 1-9.

Kitaura T, Doke S, Azuma I, Imaida M, Miyano K, Harada K, Yabuuchi E (1983) Halo production by sulfatase activity of $V$. vulnificus and $V$. cholerae $\mathrm{O} 1$ on a new selective sodium dodecyl sulfate-containing agar medium: A screening marker in environmental surveillance. FEMS Microbiology Letters, 17, 205-209.

Lane DJ (1991) 16S/23S rRNA sequencing. In: Nucleic acid techniques in bacterial systematics (ed Goodfellow SaM). Academic Press, Chichester, England, pp. 115-175.

Leavitt WD, Halevy I, Bradley AS, Johnston DT (2013) Influence of sulfate reduction rates on the Phanerozoic sulfur isotope record. Proceedings of the National Academy of Sciences, 110, 11244-11249.

Macdonald IR, Reilly JF, Guinasso NL, Brooks JM, Carney RS, Bryant WA, Bright TJ (1990) Chemosynthetic mussels at a brine-filled pockmark in the northern Gulf of Mexico. Science, 248, 1096-1099.

Mason, O.U. §, Case, D.H.§, Naehr, T.H., Lee, R.W., Thomas, R.B., Bailey, J.V., Orphan, V.J., (2015) Comparison of archaeal and bacterial diversity in methane seep carbonate nodules and host sediments, Eel River Basin and Hydrate Ridge, USA. Microbial Ecology. DOI 10.1007/s00248-015-0615-6.

Martin MW (2011) Cutadapt removes adapter sequences from high-throughput sequencing reads. EMBnet Journal 17, 10-12.

Masella AP, Bartram AK, Truszkowski JM, Brown DG, Neufeld JD (2012) PANDAseq: paired-end assembler for Illumina sequences. BMC Bioinformatics, 13, 31. 
924

925

926

927

928

929

930

931

932

933

934

935

936

937

938

939

940

941

942

943

944

945

946

947

948

949

950

951

952

953

954

955

956

957

958

959

960

961

962

963

964

965

966

967

968

969

Meyer B, Imhoff JF, Kuever J (2007) Molecular analysis of the distribution and phylogeny of the soxB gene among sulfur-oxidizing bacteria-evolution of the Sox sulfur oxidation enzyme system. Environmental Microbiology, 9, 2957-2977.

Michel G, Nyval-Collen P, Barbeyron T, Czjzek M, Helbert W (2006) Bioconversion of red seaweed galactans: a focus on bacterial agarases and carrageenases. Applied Microbiology and Biotechnology, 71, 23-33.

Milucka J, Ferdelman TG, Polerecky L, Franzke D, Wegener G, Schmid M, Lieberwirth I, Wagner M, Widdel F, Kuypers MM (2012) Zero-valent sulphur is a key intermediate in marine methane oxidation. Nature, 7425, 541-546.

Monnin C, Jeandel C, Cattaldo T, Dehairs F (1999) The marine barite saturation state of the world's oceans. Marine Chemistry, 65, 253-261.

Mukhopadhyaya PN, Deb C, Lahiri C, Roy P (2000) A soxA gene, encoding a diheme cytochrome c, and a sox locus, essential for sulfur oxidation in a new sulfur lithotrophic bacterium. Journal of Bacteriology, 182, 4278-4287.

Mußmann M, Schulz HN, Strotmann B, Kjær T, Nielsen LP, Rosselló-Mora RA, Amann RI, Jørgensen BB (2003) Phylogeny and distribution of nitrate-storing Beggiatoa spp. in coastal marine sediments. Environmental Microbiology, 5, 523-533.

Orcutt B, Boetius A, Elvert M, Samarkin V, Joye SB (2005) Molecular biogeochemistry of sulfate reduction, methanogenesis and the anaerobic oxidation of methane at Gulf of Mexico cold seeps. Geochimica et Cosmochimica Acta, 69, 4267-4281.

Orphan VJ, House CH, Hinrichs KU, Mckeegan KD, Delong EF (2001) Methaneconsuming archaea revealed by directly coupled isotopic and phylogenetic analysis. Science, 293, 484-487.

Paytan A, Kastner M, Campbell D, Thiemens MH (1998) Sulfur isotopic composition of Cenozoic seawater sulfate. Science, 282, 1459-1462.

Paytan A, Kastner M, Chavez FP (1996) Glacial to interglacial fluctuations in productivity in the equatorial Pacific as indicated by marine barite. Science, 274, 1355-1357.

Paytan A, Kastner M, Martin EE, Macdougall JD, Herbert T (1993) Marine barite as a monitor of seawater strontium isotope composition Nature, 366, 445-449.

Peckmann J, Thiel V, Reitner J, Taviani M, Aharon P, Michaelis W (2004) A microbial mat of a large sulfur bacterium preserved in a Miocene methane-seep limestone Geomicrobiology Journal, 21, 247-255.

Petri R, Podgorsek L, Imhoff JF (2001) Phylogeny and distribution of the soxB gene among thiosulfate-oxidizing bacteria. FEMS Microbiology Letters, 197, 171-178.

Podgorsek L, Imhoff JF (1999) Tetrathionate production by sulfur oxidizing bacteria and the role of tetrathionate in the sulfur cycle of Baltic Sea sediments. Aquatic Microbial Ecology, 17, 255-265.

Quast C, Pruesse E, Yilmaz P, Gerken J, Schweer T, Yarza P, Peplies J, Gloeckner FO (2013) The SILVA ribosomal RNA gene database project: improved data processing and web-based tools. Nucleic Acids Research, 41 D1: D590-D596.

Rasmussen B (2000) Filamentous microfossils in a 3,235-million-year-old volcanogenic massive sulphide deposit. Nature, 405, 676-679.

Riedinger, N., Kasten, S., Gröger, J., Franke, C., Pfeifer, K. (2006) Active and buried authigenic barite fronts in sediments from the Eastern Cape Basin. Earth and Planetary Science Letters, 241, 876-887. 
Ritger S, Carson B, Suess E (1987) Methane-derived authigenic carbonates formed by subduction-induced pore-water expulsion along the Oregon/Washington margin. Geological Society of America Bulletin, 98, 147-156.

Roberts HH, Feng D, Joye SB (2010) Cold seep carbonates of the middle and lower continental slope, northern Gulf of Mexico. Deep Sea Research, 57, 2040-2054.

Rushdi AI, Mcmanus J, Collier RW (2000) Marine barite and celestite saturation in seawater. Marine Chemistry, 69, 19-31.

Salman V, Amann R, Girnth A-C, Polerecky L, Bailey JV, Høgslund S, Jessen G, Pantoja S, Schulz-Vogt HN (2011) A single-cell sequencing approach to the classification of large, vacuolated sulfur bacteria. Systematic and Applied Microbiology, 34, 243-259.

Salman V, Amann R, Shub DA, Schulz-Vogt HN. (2012) Multiple self-splicing introns in the 16S rRNA genes of giant sulfur bacteria. Proc. Nat. Acad. Sci. U.S.A. 109, 4203- 4208.

Sanz-Montero ME, Rodríguez-Aranda JP, García Del Cura MA (2009) Bioinduced precipitation of barite and celestite in dolomite microbialites. Examples from Miocene lacustrine sequences in the Madrid and Duero Basins, Spain. Sedimentary Geology, 222, 138-148.

Schloss PD, Westcott SL, Ryabin T, Hall JR, Hartmann M, Hollister EB, Lesniewski RA, Oakley BB, Parks DH, Robinson CJ, Sahl JW, Stres B, Thallinger GG, Van Horn DJ, Weber CF (2009) Introducing mothur: Open-Source, Platform-Independent, Community-Supported Software for Describing and Comparing Microbial Communities. Appl. Environ. Microbiol., 75, 7537-7541.

Scott KM, Sievert SM, Abril FN, Ball LA, Barrett CJ, Blake RA, Boller AJ, Chain PS, Clark JA, Davis CR, Detter C, Do K, Dobrinski KP, Faza BI, Fitzpatrick KA, Freyermuth SK, Harmer TL, Hauser LJ, Hugler M, Kerfeld CA, Kong WW, Land M, Lapidus A, Larimer FW, Longo DL, Lucas S, Malfatti S, Massey SE, Martin DD, Mccuddin Z, Meyer F, Moore JL, Ocampo LH, Paul JH, Paulsen IT, Reep DK, Ren Q, Ross RL, Sato PY, Thomas P, Tinkham LE, Zeruth GT (2006) The genome of the deep-sea vent chemolithoautotroph Thiomicrospira crunogena. PLoS Biology, 4, 1-17.

Sekar R, Mills DK, Remily ER, Voss JD, Richardson LL. (2006) Microbial communities in the surface mucopolysaccharide layer and the black band microbial mat of black band-diseased Siderastrea siderea. Appl. Environ. Microbiol. 72, 5963-5973.

Senko JM, Campbell BS, Henriksen JR, Elshahed MS, Dewers TA, Krumholz LR (2004) Barite deposition resulting from phototrophic sulfide-oxidizing bacterial activity. Geochimica et Cosmochimica Acta, 68, 773-780.

Shen Y, Buick R, Canfield DE (2001) Isotopic evidence for microbial sulphate reduction in the early Archaean era. Nature, 410, 77-81.

Sim MS, Bosak T, Ono S (2011) Large sulfur isotope fractionation does not require disproportionation. Science, 333, 74-77.

Sorokin DY, Teske A, Robertson LA, Kuenen JG (1999) Anaerobic oxidation of thiosulfate to tetrathionate by obligately heterotrophic bacteria, belonging to the Pseudomonas stutzeri group. FEMS Microbiology Ecology, 30, 113-123. 
1015 Spirakis CS (1991) The possible role of thiosulfate in the precipitation of 34S-rich barite in some Mississippi Valley-type deposits. Mineralium Deposita, 26, 60-65.

Stroobants N, Dehairs F, Goeyens L, Vanderheijden N, Van Grieken R (1991) Barite formation in the Southern Ocean water column. Marine Chemistry, 35, 411-421.

Swofford D (1999) Phylogenetic analysis using parsimony (and other methods) PAUP* 4.0. Sinauer, Sunderland.

Teske A, Brinkhoff T, Muyzer G, Moser D, Rethmeier J, Jannasch HW (2000) Diversity of thiosulfate-oxidizing bacteria from marine sediments and hydrothermal vents. Applied and Environmental Microbiology, 66, 3125-3133.

Torres ME, Bohrmann G, Dube TE, Poole FG (2003) Formation of modern and Paleozoic stratiform barite at cold methane seeps on continental margins. Geology, 31, 897-900.

Torres ME, Bohrmann G, Suess E (1996) Authigenic barites and fluxes of barium associated with fluid seeps in the Peru subduction zone. Earth and Planetary Science Letters, 144, 469-481.

Van Der Wielen PWJJ, Bolhuis H, Borin S, Daffonchio D, Corselli C, Giuliano L, D'auria G, De Lange GJ, Huebner A, Varnavas SP, Thomson J, Tamburini C, Marty D, Mcgenity TJ, Timmis KN, Party BS (2005) The Enigma of Prokaryotic Life in Deep Hypersaline Anoxic Basins. Science, 307, 121-123.

Wankel SD, Bradley AS, Eldridge DL, Johnston DT (2014) Determination and application of the equilibrium oxygen isotope effect between water and sulfite. Geochimica et Cosmochimica Acta, 125, 694-711.

Zerkle AL, Farquhar J, Johnston DT, Cox RP, Canfield DE (2009) Fractionation of multiple sulfur isotopes during phototrophic oxidation of sulfide and elemental sulfur by a green sulfur bacterium. Geochimica et Cosmochimica Acta, 73, 291306.

1041

1042

1043 